
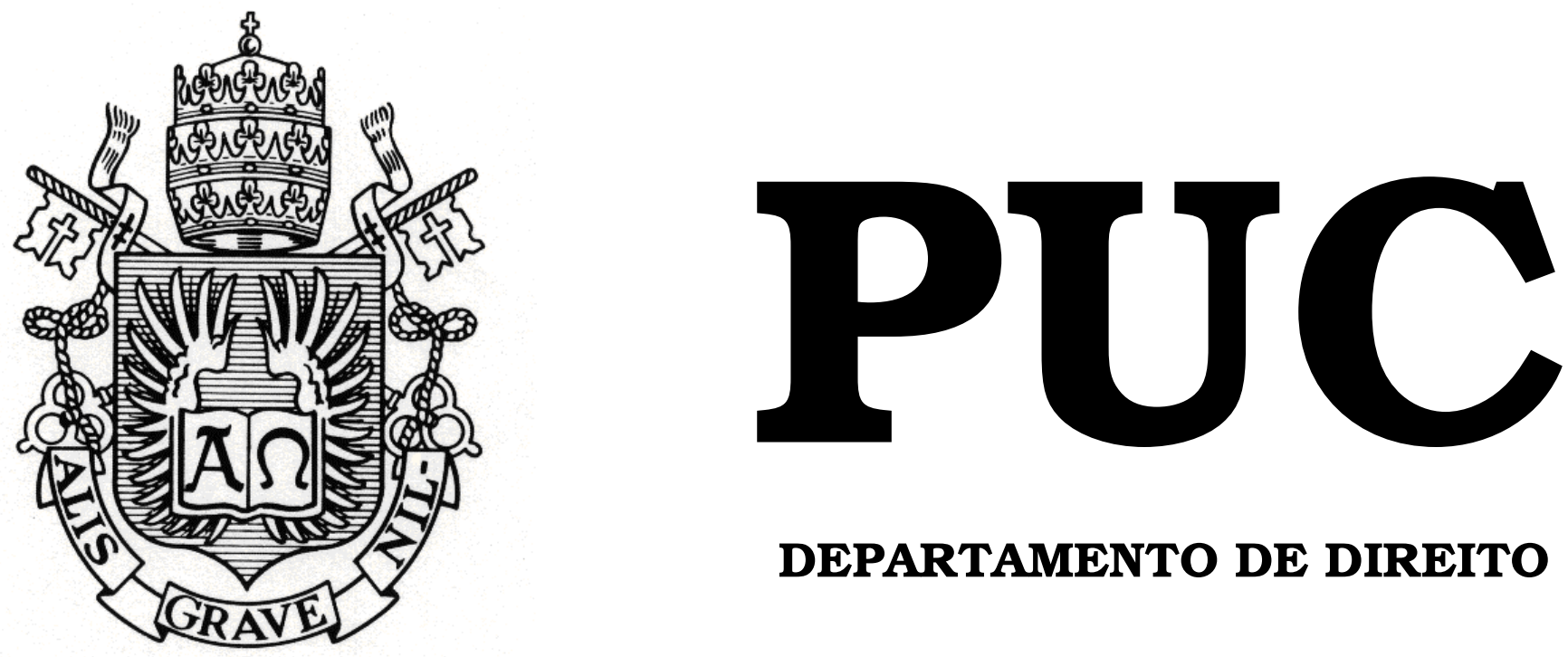

DEPARTAMENTO DE DIREITO

O DIREITO À INTIMIDADE FACE À LIBERDADE DE COMUNICAÇÃO SOCIAL NA CONSTITUIÇÃO DE 1988: UMA NOVA VISÃO DO “CONFLITO”

por

FERNANDA DA SILVA BARBOZA LIMA

ORIENTADOR: Adriano Pilatti

2005.1

PONTIFÍCIA UNIVERSIDADE CATÓLICA DO RIO DE JANEIRO

RUA MARQUÊS DE SÃO VICENTE, 225 - CEP 22453-900

RIO DE JANEIRO - BRASIL 


\section{O DIREITO À INTIMIDADE FACE À LIBERDADE DE COMUNICAÇÃO SOCIAL NA CONSTITUIÇÃO DE 1988: UMA NOVA VISÃO DO “CONFLITO"}

por

FERNANDA DA SILVA BARBOZA LIMA

Monografia

apresentada

ao

Departamento de Direito da Pontifícia Universidade Católica do Rio de Janeiro (PUC-Rio) para a obtenção do Título de Bacharel em Direito.

Orientador: Adriano Pilatti 
Agradeço a Deus, meu refúgio e fortaleza, socorro bem presente nas tribulações;

à minha mãe Fátima, dedicação integral e incondicional, um modelo de mulher, de pessoa, de mãe, que abriu mão de ser feliz para que eu

pudesse ser;

à minha irmã Carolina, pela força e orgulho que tem de mim, infinitamente menor do que o que eu tenho por ela;

à minha irmã Luciana, pelo amor e prestatividade em todos os momentos, a quem devo a entrega deste trabalho a tempo; ao meu pai, de quem herdei muitas qualidades (e defeitos); à minha avó Zelma, presente de Deus na minha vida, que Ele achou por bem levar mais cedo;

ao João Pedro, mais que amigo, mais que namorado, meu amor, presente em tudo que me aconteceu de bom e ruim durante esses quase quatro anos, fonte de constantes lições de caráter, ética e respeito que mudaram a minha vida e têm feito de mim uma pessoa melhor;

à Jeniffer Moreira, Rachel Eto, Carolina Diniz, Priscilla Bonaparte, Liliana Rodrigues e Mariana Corrêa, melhores alunas e amigas da turma, pela amizade, carinho e paciência dispensados durante esses cinco anos de muitos estudos, risadas, almoços e amigos-nem-tão-ocultos-assim; aos amigos do CAEL, pelos momentos mais engraçados e construtivos da minha vida;

à Maria Cristina Manella Cordeiro, pelo incentivo nesses últimos anos de faculdade, pessoa fundamental na escolha da minha futura carreira;

a Felipe Santa Cruz, ex-chefe e sempre amigo, brilhante em tudo que

faz;

aos professores Ronaldo Cramer, Marcelo Trindade, Otávio Bravo, Julian

Chediak, Marcelo Ferro, Álvaro Piquet, Carlos Henrique Bechara e

Francisco de Guimaraens, pela confiança em mim depositada e pelos ensinamentos de Direito e de vida, em especial ao mestre Adriano Pilatti, um misto de experiência, conhecimento e genialidade;

por fim, mas não menos importante, ao professor Augusto Sampaio, que permitiu que eu prosseguisse dignamente nessa caminhada que hoje se 


\section{Sumário}

Resumo

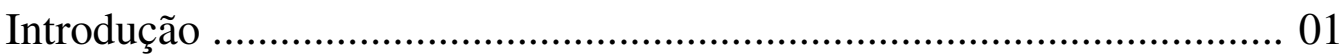

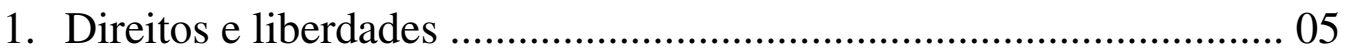

1.1. Direitos e garantias ....................................................... 05

1.2. Intimidade, vida privada, honra e imagem ......................... 08

1.3. Liberdade de expressão e liberdade de imprensa .................. 16

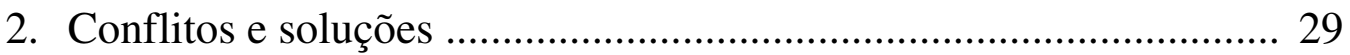

2.1. Auto-regulamentação ....................................................... 40

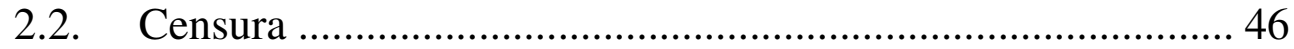

2.3. Reparação civil e proibição de divulgar .............................. 49

2.4. Mídia e interesse público ............................................. 54

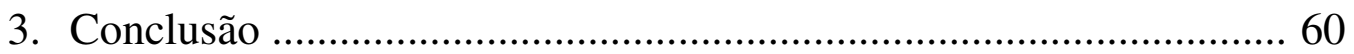

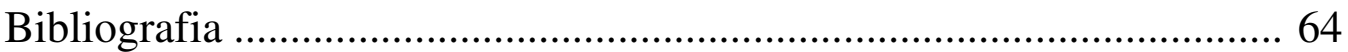




\section{Resumo}

A monografia que se segue pretende oferecer um novo norte ao suposto conflito entre direito à intimidade e liberdade de imprensa, a partir de uma ótica conceitual dos institutos que os cercam. Com base nessa premissa, procura-se fornecer, através da análise das definições oferecidas pela doutrina, mormente a nacional, uma aplicação à ordem constitucional e à legislação vigente.

Momentos há em que se tornará necessário mencionar dispositivos e conceitos de outros ordenamentos jurídicos, sem perder-se de vista que a análise, posto que possa em algum momento aplicar-se àqueles, prende-se sobretudo aos dispositivos legais e constitucionais brasileiros que tutelam a inviolabilidade da intimidade e consagram a liberdade de expressão.

Enquanto a doutrina busca uma solução do aparente conflito em teorias que na verdade nada mais fazem que repetir o próprio ofício do julgador, qual seja decidir no caso concreto qual direito terá êxito na lide, almeja-se, antes de adentrar no campo fático, verificar a existência ou não do conflito, a partir da abrangência daqueles direitos em questão, com base no estabelecimento, se possível, de critérios gerais.

Palavras-chave: Privacidade. Intimidade. Vida privada. Liberdade de imprensa. Liberdade de comunicação social. Liberdade de manifestação de pensamento. Liberdade de expressão. Conflito. Interesse Público. 


\section{Introdução}

O presente trabalho visa analisar o direito à intimidade, em seus aspectos mais relevantes, sobretudo diferenciando-o de outros a ele semelhantes, e quando em conflito com outro direito, ou melhor, liberdade, qual seja a liberdade de expressão. Como já é certo na doutrina que não há direito constitucional absoluto, podemos enfrentar a possibilidade de eventual limitação.

Merece destaque o tema ora apresentado tendo-se em vista o avanço tecnológico midiático, seja tratando-se da vida de pessoas tidas como "públicas" ou de cidadãos "comuns". Tanto em uma como em outra situação pode-se invocar um ou outro desses direitos.

Se por um lado há um aprimoramento dos veículos de comunicação de massa, de outro há uma constante busca pelo resguardo da privacidade. Há, destarte, atualmente, uma constante preocupação com a proteção à privacidade contra excessos da imprensa que por vezes incidem no íntimo de cada pessoa, expondo-a ou infamando atos de sua vida privada.

Como se sabe, a liberdade de expressão, sobretudo no contexto brasileiro, sempre foi um campo muito delicado a se discutir acerca de possível limitação, em razão do período autoritário, o que levou a Constituição de 1988 a preocupar-se especialmente com os abusos sob os quais viveu a população.

Entretanto, o direito à intimidade representa uma norma constitucional de caráter principiológico e, assim sendo, de mesma natureza que a liberdade de expressão ${ }^{1}$. Há, destarte, um patente conflito entre o interesse público de ser informado através da imprensa e o interesse

\footnotetext{
${ }^{1}$ BASTOS, Celso Ribeiro. Os limites à liberdade de expressão na Constituição da República. Revista Forense. Ano 96, vol. 349, p. 45. jan.- fev. 2000.
} 
profissional do próprio jornalista de noticiar, de um lado, e o interesse privado de manter sua privacidade protegida, de outro.

Deve-se advertir que não se pretende analisar com profundidade a teoria da ponderação de interesses, tema que dependeria de profunda análise crítica, sobretudo no que respeita aos seus fundamentos e a sua aplicação prática. A mencionada teoria será apenas apresentada como exemplo de alternativa à solução do conflito.

O ano passado foi especialmente marcado pela discussão acerca restrição do uso do "jornalismo investigativo", em situações quase sempre ligadas à Presidência da República. Os casos envolvendo Waldomiro Diniz, assessor da Casa Civil da Presidência, amplamente divulgado pela mídia e a publicação, pelo New York Times, de matéria sobre suposto hábito de beber do presidente Lula, levantaram o debate no que respeita ao direito à intimidade de pessoas que exercem atividade pública.

Podemos observar nitidamente dois pólos distintos: de um lado, os jornalistas e os proprietários dos meios de comunicação que repudiam qualquer investida semelhante à censura, acompanhados por alguns políticos, juristas e intelectuais; de outro, o governo e membros do Poder Judiciário defendendo a imposição de limites.

Sobretudo em relação aos acontecimentos mencionados, o Governo Federal apresentou a proposta de criação do Conselho Federal de Jornalismo, através do Projeto de Lei 3985/2004, com a função de orientar, regulamentar, disciplinar e fiscalizar o exercício profissional do jornalista, submetendo-se a um Código de Ética, prevendo infrações disciplinares e suas respectivas penalidades, tais como advertência, multa, censura, suspensão e até cassação.

O Projeto foi, como não poderia deixar de ser, altamente criticado tanto por membros do Poder Legislativo, como por órgãos de classe, o que levou ao seu arquivamento. As referências ao Projeto neste presente trabalho servirão apenas como base para a finalidade aqui 
proposta, qual seja, identificar a possibilidade de limitar uma liberdade constitucional de caráter público em razão de um direito individual também constitucional.

Não há que se negar a função fiscalizadora da mídia ${ }^{2}$, mas o que examinaremos aqui serão as eventuais alternativas de regulação, sua legitimidade e legalidade. Para que seja possível uma análise mais cuidadosa do tema, serão aqui trazidas algumas decisões judiciais e doutrina, de acordo com a Constituição de 1988.

O interesse pessoal na matéria antecede os últimos cinco anos de graduação de Direito, haja vista ter antes cursado, ainda que somente por três semestres, a Faculdade de Comunicação Social, abrangendo quase toda a parte teórica do mesmo. Através da experiência na área de assessoria de imprensa, pôde-se perceber a relação turbulenta, posto que necessária, entre a mídia e as pessoas cujas notícias supostamente interessam ao público.

Precisa-se partir da investigação da titularidade e do regular uso de tais direitos confrontados. E mais: se for possível admitir a vedação de qualquer tipo de regulamentação, prévia ou posterior, será razoável aceitar a total irresponsabilidade dos meios de comunicação, sempre lastreados pelo sigilo da fonte ou na própria liberdade de manifestação do pensamento? Sim, porque se há interesses na divulgação de determinados fatos, pode haver a total desnecessidade de publicação de outros, aparentemente relevantes.

De que modo os mecanismos podem ser utilizados, seja para coibir como para punir os responsáveis pelos excessos sem recair na discussão acerca da censura? Se já está estabelecido que qualquer censura ou exigência de licença é vedada, é possível evitar a ocorrência do dano? Mesmo que fossem permitidos, esses mecanismos aplicar-se-iam à hipótese em questão?

\footnotetext{
2 ZIMMERMANN, Augusto. Curso de direito constitucional. $2^{\mathrm{a}}$ ed. ampliada. Rio de Janeiro: Lumen Juris, 2002. p. 268.
} 
Quem defende a regulamentação da profissão jornalística a partir de soluções éticas com a criação de Conselhos, busca suporte em outros exemplos, tais como o CONAR (Conselho Nacional de AutoRegulamentação Publicitária), que estabeleceu limites à veiculação de publicidade enganosa.

Há também outros exemplos de órgãos de classe, com suas peculiaridades, que fiscalizam e decidem internamente, sobretudo no que se refere à ética e ao regular exercício da profissão, como o que ocorre na própria Ordem dos Advogados do Brasil e em outras tantas profissões (Engenharia, Arquitetura, Corretagem de imóveis, Medicina, etc.).

$\mathrm{Na}$ história brasileira, a liberdade de comunicação social que desenvolve relevante papel para a formação cultural, intelectual e artística, bem como na físcalização da atuação do governo, já sofreu em circunstâncias extremamente delicadas para o país imensas restrições, tornando a relação entre a imprensa e o Estado sempre turbulenta.

Por outro lado, o direito à intimidade já se encontra protegido em uma série de outros direitos individuais, tais como a inviolabilidade de domicílio, o sigilo de correspondência, a imagem, a honra, etc.

Primeiramente, pois, torna-se necessário conceituar tanto o direito à intimidade, como a liberdade de expressão, situando-os juridicamente e diferenciando-os dos que lhes são semelhantes, como já se estabeleceu de início e por onde entende-se como o melhor começo desta abordagem. Em alguns momentos, frise-se, os termos "intimidade" e "vida privada" poderão ser confundidos ou utilizados como sinônimos, sem perder a sua essência, ou incorrer em equívoco. 


\section{Direitos e liberdades}

\subsection{Direitos e garantias}

Como bem asseverou Rui Barbosa, não há que se confundir direitos e garantias, já que existem "no texto de lei fundamental, as disposições meramente declaratórias, que são as que imprimem existência legal aos direitos reconhecidos, e as disposições assecuratórias, que são as que, em defesa dos direitos, limitam o poder. Aquelas instituem direitos; estas as garantias: ocorrendo não raro juntar-se, na mesma disposição constitucional, ou legal, a fixação da garantia com a declaração do direito"3

Para Canotilho ${ }^{4}$, as garantias também configuram direitos, não obstante possuam um caráter eminentemente instrumental. Traduzem-se no direito dos cidadãos de exigir dos poderes públicos a proteção de seus direitos ou no reconhecimento de meios processuais adequados a essa finalidade.

Diferenciação semelhante faz Jorge Miranda, ao estabelecer que:

"Os direitos representam só por si certos bens, as garantias destinam-se a assegurar a fruição desses bens; os direitos são principais, as garantias acessórias e, muitas delas, adjectivas (ainda que possam ser objecto de um regime constitucional substantivo); os direitos permitem a realização das pessoas e inserem-se directa e imediatamente, por isso, nas respectivas esferas jurídicas, as garantias só nelas se projectam pelo nexo que possuem com os direitos; na acepção jusracionalista inicial, os direitos declaram-se, as garantias estabelecem-se",

Ou seja, como ressaltado por Maurice Hauriou, não basta o reconhecimento e a declaração de um direito, é necessário garanti-lo, pois

\footnotetext{
${ }^{3}$ BARBOSA, Rui. República: teoria e prática. Petrópolis-Brasilia: Vozes/Câmara dos Deputados, 1978. p. 121. Apud: BULOS, Uadi Lammêgo. Constituição federal anotada. $4^{a}$ ed. São Paulo: Saraiva, 2002. p. 72.

${ }^{4}$ CANOTILHO, J. J. Gomes. Direito Constitucional e teoria da constituição. $2^{\mathrm{a}}$ ed. Coimbra: Almedina, 1998. p. 362 et seq.

${ }^{5}$ MIRANDA, Jorge. Manual de direito constitucional. $4^{\mathrm{a}}$ ed. Coimbra: Coimbra Editora, 1990. p. 88-89. Apud: MORAES, Alexandre de. Direito constitucional. $8^{a}$ ed. São Paulo: Atlas, 2000. p. 60.
} 
haverá ocasiões em que ele será discutido e violado. ${ }^{6}$ A Constituição de 1988, contudo, não diferenciou direitos de garantias.

A doutrina emprega a expressão garantias constitucionais em três sentidos: 1) reconhecimento constitucional dos direitos fundamentais; 2) vedações ao abuso do poder público; 3) proteção efetiva da liberdade e dos direitos que assegura. ${ }^{7}$

Canotilho, mais minuciosamente, adota a seguinte classificação dos direitos e garantias, a partir de uma visão tridimensional dos direitos fundamentais (jusnaturalista, universalista e constitucional): 1) direitos do homem, válidos para todos os povos e em todos os tempos (visão jusnaturalista-universalista), decorrentes da própria natureza humana e por isso invioláveis, intemporais e universais; e direitos fundamentais, direitos do homem jurídico-institucionalmente garantidos e limitados no espaço e no tempo - objetivamente vigente em uma ordem jurídica concreta; 2) direitos do homem, enquanto tal e direitos do cidadão, do homem enquanto ser social, como indivíduo vivendo em sociedade ${ }^{8}$; 3 ) direitos naturais, inerentes ao indivíduo e anteriores a qualquer contrato social, e direitos civis, pertencentes ao indivíduo como cidadão, proclamados nas Constituições ou leis avulsas ${ }^{9}$; 4) direitos civis, reconhecidos pelo direito positivo a todos os homens que vivem em sociedade, e direitos políticos, aqueles só atribuídos aos cidadãos ativos ${ }^{10}$; 5) direitos civis e direitos ou liberdades individuais ${ }^{11}$, expressão esta entendida sobretudo no sentido de direitos públicos individuais, isto é, concernentes à liberdade, à segurança individual e à propriedade; 6) direitos e liberdades públicas - o primeiro se refere ao status activus, ou seja, à participação do cidadão como elemento

\footnotetext{
${ }^{6}$ HARIOU, Maurice. Derecho público y constitucional. $2^{\mathrm{a}}$ ed. Madrid, Reus, s.d., trad. De Carlos Ruiz del Castillo. Apud: SILVA, José Afonso da. Curso de direito constitucional positivo. $19^{\mathrm{a}}$ ed. São Paulo: Malheiros, 2001. p. 189.

${ }^{7}$ SILVA, José Afonso da. Op. cit., p. 190.

${ }^{8}$ Seqüela da separação sociedade-Estado. A sociedade civil seria apolítica por essência.

${ }^{9}$ Derivada dos Civil Rights dos Estados Unidos.

${ }^{10}$ Classificação esta adotada por Sieyés, como fundamento do voto censitário. Proclamava, com isto, a igualdade, evitando, contudo, o sufrágio universal.
} 
ativo da vida política ${ }^{12}$, já as liberdades públicas visam defender a esfera dos cidadãos perante a intervenção do Estado (status negativus) ${ }^{13}$; 7) direitos e garantias (conforme já explicado acima); 8) direitos fundamentais e direitos da personalidade, estes entendidos como direitos de estado ou direitos sobre a própria pessoa (distintivos da personalidade e muitos diretos de liberdade, tais como a liberdade de expressão); 9) direitos fundamentais e garantias institucionais (garantias jurídico-públicas e jurídico-privadas) ${ }^{14}$.

José Afonso da Silva ${ }^{15}$ acrescenta que as garantias dos direitos fundamentais podem ser divididas em garantias gerais, assegurando a existência e a efetividade dos direitos, e garantias constitucionais, consistentes nas instituições, determinações e procedimentos para a tutela pela própria Constituição da observância ou reintegração dos direitos fundamentais. Estas últimas podem ser gerais, quando dizem respeito a instituições de caráter constitucional que se inserem no mecanismo de freios e contrapesos dos poderes, impedindo o arbítrio, e técnicas de garantia e respeito aos direitos fundamentais, e especiais, que estatuem técnicas e mecanismos limitadores da atuação estatal ou particular, protegendo a eficácia, a aplicabilidade e a inviolabilidade dos direitos de modo especial.

As garantias constitucionais especiais são verdadeiros instrumentos para a tutela de um direito principal e por isso mesmo não são

\footnotetext{
11 A opção pela designação de direitos individuais reflete melhor, para Canotilho, a filosofia individualista da escola liberal.

12 Também denominados direitos políticos, direitos do cidadão, liberdades de participação. São posições jurídicas do cidadão em conexão com o status positivus - direito às prestações necessárias ao desenvolvimento pleno da existência individual. Direitos positivos ou direitos de prestação.

${ }^{13}$ Também chamado direito de liberdade e direitos negativos.

${ }^{14}$ As instituições têm sujeito e objeto diferente dos direitos do cidadão, tais como a maternidade, a família, a imprensa livre que só indiretamente se expandem para a proteção dos direitos individuais. Não garantem aos particulares posições subjetivas autônomas e daí a inaplicabilidade do regime dos direito, liberdades e garantias. Exceção: interseção de garantias institucionais e de garantias de direitos fundamentais (indissociável a proteção do direito de liberdade de imprensa da proteção da imprensa livre, por exemplo). Aproxima-se da proteção dos direitos fundamentais quando se exige, face às intervenções limitativas do legislador, a salvaguarda do mínimo essencial das instituições. Cf. CANOTILHO, J. J. Gomes. Ob.cit. p. 362 et seq.
} 
um fim em si mesmo, como o são os direitos fundamentais. São instrumentais, mas não deixam de ser também direitos, conexos com direitos fundamentais.

Para José Afonso da Silva, as garantias constitucionais especiais são os autênticos direitos públicos subjetivos, visto que importam, sobretudo ao Poder Público, através de sua concessão a particulares por normas jurídicas constitucionais, imposições positivas ou negativas, destinadas a fazer valer os direitos garantidos. Tendo em vista o direito garantido, podem ser individuais, coletivas, sociais e políticas.

\subsection{Intimidade, vida privada, honra e imagem}

A proteção jurídica da intimidade guarda íntima relação com a estrutura da sociedade e tem seu surgimento relacionado com a transformação da sociedade rural em industrializada, no êxodo do campo para a cidade. Alega-se isto, pois no meio rural, pela distância entre propriedades e o conseqüente isolamento natural das pessoas, era favorecida a solidão, impelindo o homem a buscar relações sociais e íntimas.

Com a Revolução Industrial, no século XIX, os homens se vêem forçados a conviver em ambientes comuns e em habitações coletivas, dando origem a um interesse à reserva. O tipo de vida imposto pela cidade dificulta o isolamento moral. "A variedade de ambientes legitima a pretensão de a pessoa controlar as informações referentes a si própria, de modo a filtrá-las e a evitar que determinados aspectos de sua personalidade, embora conhecidos em um determinado ambiente, não o sejam em outros ambientes onde possivelmente não seriam bem aceitos" 16 .

\footnotetext{
${ }^{15}$ SILVA, José Afonso da. Op. cit. p. 191-192 e 416.

${ }^{16}$ CARVALHO, Luiz Gustavo Grandinetti Castanho de. Liberdade de informação e o direito difuso à informação verdadeira. $2^{\mathrm{a}}$ ed. Rio de Janeiro: Renovar, 2003. p. 251.
} 
A privacidade encontra uma de suas maiores referências na publicação, em 1890, do ensaio "The Right of Privacy”, elaborado pelos advogados Dennis Warren e Louis Dembitz Brandeis, a partir da análise dos excessos da imprensa norte-americana no caso Olmstead v. United States, verificando a finalidade puramente comercial na exposição da intimidade de pessoas públicas. "O ensaio expressava o quanto a imprensa havia ultrapassado as fronteiras da prudência e da decência, comprovando que 'as fofocas' já não eram mais recurso de ociosos e corruptos, mas sim, grandes e proveitosas atividades comerciais que visavam ao lucro. Brandeis e Warren chegaram a observar o quanto satisfaziam ao público as fofocas sobre detalhes das relações sexuais das pessoas públicas. O ensaio precursor da matéria já demonstrou o conflito entre direito à intimidade e direito à informação, paradigma permanente na trajetória dessa matéria" 17 .

Antes, contudo, houve ainda uma tentativa de separação do direito do autor (de caráter pecuniário) do direito ao segredo das partes vulneráveis da vida privada, através do trabalho de I. Kohler, em 1880, na Alemanha.

Henkel, em 1958, teria sido o responsável por decompor a intimidade em três círculos concêntricos. O primeiro e maior deles corresponderia à esfera da vida privada em seu sentido estrito (Privatsphäre), compreendendo os comportamentos e acontecimentos que o indivíduo não quer que se tornem públicos. O círculo de tamanho intermediário representaria a esfera da intimidade (Vertrauensphäre), nele inseridos os acontecimentos que o titular só compartilha com pessoas em quem deposita certa dose de confiança. Por fim, o círculo de menor raio

\footnotetext{
${ }^{17}$ AIETA, Vânia Siciliano. A garantia da intimidade como direito fundamental. Rio de Janeiro: Lumen Juris, 1999. p. 81. Neste caso, a intimidade do jurista Samuel Dennis Warren tinha sido violada por um jornal. Ele havia se casado com a filha de um senador, mas supostamente tinha uma amante. Com esta monografia, conseguiram os seus autores desviar a noção de intimidade do direito à honra e da noção de propriedade privada, resumida na célebre frase "My home is my castle", passando a jurisprudência americana a adotar um conceito moderno do direito à intimidade.
} 
seria a esfera do segredo (Geheimsphäre), de conhecimento exclusivo do titular ou de pessoa especialmente autorizada. ${ }^{18}$

$\mathrm{O}$ primeiro documento a afeiçoar estes direitos de forma explícita foi a Declaração Americana dos Direitos e Deveres do Homem, aprovada em Bogotá, em 02 de maio de 1948. Logo depois, a Declaração Universal dos Direitos Humanos, de 1948, protegeu também esses direitos de qualquer interferência naqueles direitos.

Esses direitos (intimidade, vida privada, honra e imagem) estão assegurados na maioria das constituições. A Lei Fundamental de Bonn, de 1949, em seu artigo $2^{\circ}$, traz o direito ao livre desenvolvimento da intimidade, permitindo a formulação de uma corrente jurisprudencial no sentido de agasalhar aquele direito. A Constituição Portuguesa, de 1976, no artigo 33 é clara ao proteger "a intimidade da vida privada e familiar". As Cartas da Iugoslávia, de 1974, e da União Soviética, de 1977, países extintos, previam-na de forma expressa. A proteção foi acolhida pela França em 1970 através de lei que modificou os Códigos Civil e Penal. Finalmente, na Itália, depois de muita discussão acerca da previsão constitucional da tutela da intimidade, ficou superada a questão com a adesão ao Convênio Europeu dos Direitos do Homem, de 1950.

Nos textos constitucionais brasileiros anteriores à Constituição de 1988 somente se tratava do direito à intimidade de forma indireta. ${ }^{19}$

A Constituição do Império, de 1824, consagrou a inviolabilidade do domicílio e da correspondência, prevendo a responsabilidade pelos abusos cometidos no exercício do direito à informação.

A Constituição da República, de 1891, não fez grandes modificações na estrutura dos direitos individuais, dentre os quais o direito à intimidade continuou a ser garantido de forma indireta, no bojo da inviolabilidade do domicílio e da correspondência. Ampliou a proteção dos

\footnotetext{
${ }^{18}$ COSTA JR., Paulo José da. O direito de estar só. $2^{\text {a }}$ ed. São Paulo: Revista dos Tribunais, 1995. Apud: CARVALHO, Luiz Gustavo Grandinetti Castanho de. Op. cit. p. 252-253.
} 
direitos individuais para estrangeiros e assegurou a tutela de outros direitos não previstos na Constituição.

Em 1934, a Constituição estabeleceu a tutela da liberdade de consciência e de crença, a inviolabilidade do sigilo da correspondência e do domicílio, bem como dos direitos relativos à segurança individual.

A restrição à inviolabilidade do domicílio e da correspondência veio com a Constituição do Estado Novo, de 1937. Por outro lado, assegurou o direito de resposta face aos abusos cometidos pela imprensa na divulgação de informações que viessem a lesar a reputação dos indivíduos.

Recorda Vânia Siciliano Aieta ${ }^{20}$ que a primeira referência explícita ao direito à intimidade se deu na Lei 5250/67, prevendo a responsabilidade civil para violação do respeito à intimidade do indivíduo, principalmente se a divulgação não estivesse fundada em interesse público. Indiretamente, foi tutelada a intimidade pela Lei 4898, de 9 de dezembro de 1965 - Lei de abuso de autoridade.

Com a Constituição de 1967, a intimidade foi tutelada de forma indireta no $\$ 9^{\circ}$ do artigo 150 , no que concerne à inviolabilidade de correspondência, das comunicações telefônicas e telegráficas e do domicílio. A imagem, também amparada pela tutela à intimidade, não gozava de proteção expressa. A matéria era entendida pelos tribunais como amparada pelo artigo 666, inciso X, do Código Civil de 1916, posteriormente derrogado pelo artigo 49, inciso I, alínea "f", da Lei 6988/73, ao tratar sobre o direito do autor.

A Lei 6368, de 21 de outubro de 1976, previu o respeito ao direito à intimidade a partir da proteção da imagem das pessoas envolvidas no tráfico de drogas.

Por fim, é de se ressaltar a Lei 7232, de 29 de outubro de 1984, que estabeleceu, em relação à política nacional de informática, a proteção

\footnotetext{
${ }^{19}$ AIETA, Vânia Siciliano. Op. cit. p.239.
} 
ao sigilo de dados armazenados, processados e veiculados, que dissessem respeito ao direito à intimidade.

Na Constituição de 1988, superando omissão da anterior que não mencionava textualmente a existência desses direitos, assegurou-se o direito à intimidade, à vida privada, à honra e a imagem, resguardando o direito à indenização por danos material ou moral em decorrência de possível violação (artigo $5^{\circ}$, inciso X). A ampla publicidade, devassando a vida privada e a intimidade das pessoas, desfigurando sua imagem e sua honra, parece ter motivado a inclusão destes dispositivos no texto constitucional.

A intimidade ainda foi tutelada pelo constituinte brasileiro, posto que de forma indireta, através de vários outros dispositivos, tais como o direito de resposta (artigo $5^{\circ}$ inciso $\mathrm{V}$ ); a inviolabilidade do domicílio (artigo $5^{\circ}$ inciso XI); a inviolabilidade do sigilo de correspondência, das comunicações telegráficas, de dados e das comunicações telefônicas, salvo restrição judicial (artigo $5^{\circ}$ inciso XII); o resguardo da fonte, quando necessário ao exercício profissional, em se tratando de acesso à informação (artigo $5^{\circ}$ inciso XIV); o direito de inédito no universo do direito autoral e da propriedade industrial (artigo $5^{\circ}$ incisos XXVII e XXIX); o direito à imagem (artigo $5^{\circ}$ inciso XXVIII, alínea “a”); a restrição à publicidade dos atos processuais (artigo $5^{\circ}$ inciso LX) e o habeas data (artigo $5^{\circ}$ inciso LXXII).

Escreve J.M. Othon Sidou que "o direito à intimidade é, pois, o direito à dignidade, desde que é aí que ele vai buscar todo o seu conteúdo digno". 21

A doutrina entende de forma majoritária ${ }^{22}$ que o direito à intimidade insere-se entre os direitos da personalidade, especialmente os

\footnotetext{
${ }^{20}$ AIETA, Vânia Siciliano. Op. cit. p. 242.

${ }^{21}$ J.M. Othon Sidou, Direito à Intimidade. Revista da Faculdade de Direito de Caruaru. Caruaru, 7:151-2, ano XII. Apud: CRETELLA Jr., José. Comentários à Constituição de 1988. $3^{\mathrm{a}}$ ed. São Paulo: Forense Universitária, 1994. p. 79.

${ }^{22}$ Veja-se, por exemplo, CARVALHO, Luiz Gustavo Grandinetti Castanho de.Op. cit. p. 54; BARROSO, Luís Roberto. Colisão entre liberdade de expressão e direitos da personalidade.
} 
direitos à integridade moral da pessoa, ao lado do direito à privacidade, à imagem e à honra.

Apesar de serem considerados sinônimos, o direito à intimidade e o direito à privacidade são distintos, haja vista que a Constituição de 1988, quando trouxe a proteção da intimidade e da vida privada o fez separadamente. É que ambos os conceitos não se confundem. A terminologia "privacidade" pertence ao direito anglo-americano (right of privacy), enquanto "intimidade" é mais adotada pelos povos latinos.

José Afonso da Silva, de modo a abarcar todas as manifestações da esfera íntima, privada e da personalidade, preferiu utilizar a expressão direito à privacidade. Privacidade seria, assim, "o conjunto de informação acerca o indivíduo que ele pode decidir manter sob seu exclusivo controle, ou comunicar, decidindo a quem quando, onde e em que condições, sem a isso poder ser legalmente sujeito" 23 .

Segundo René Ariel Dotti, a intimidade representa "a esfera secreta da vida do indivíduo na qual este tem o poder legal de evitar os demais" ${ }^{24}$, abrangendo, neste sentido, a inviolabilidade do domicílio, o sigilo da correspondência, o segredo profissional.

Define J. Cretella Jr. a intimidade como "status ou situação daquilo que é íntimo, isolado, só. Há um direito ou liberdade pública de estar só, de não ser importunado, devassado, visto por olhos estranhos". 25

Já para L. G. Grandinetti Castanho de Carvalho, seguindo a definição de Aurelia Maria Romero Coloma, intimidade é o direito em virtude do qual excluímos a todas ou determinadas pessoas do

Critérios de ponderação. Interpretação constitucionalmente adequada do Código Civil e da Lei de Imprensa. Revista Trimestral de Direito Civil. Rio de Janeiro, v.16, p. 74, out.-dez. 2003; FARIAS, Edilsom Pereira de. Colisão de direitos: a honra, a intimidade, a vida privada e a imagem versus a liberdade de expressão e informação. $2^{\mathrm{a}}$ ed. Porto Alegre: Sergio Antonio Fabris Editor, 2000, p.

${ }^{23}$ PEREIRA, J. Matos. Direito de informação. Lisboa: Associação Portuguesa de Informática, 1980. p. 15. Apud: SILVA, José Afonso da. Op. cit. p. 209.

${ }^{24}$ DOTTI, René Ariel. Proteção da vida privada e liberdade de informação. São Paulo: Revista dos Tribunais, 1980. Apud: SILVA, José Afonso da. Op. cit. p. 210.

${ }^{25}$ CRETELLA Jr., José. Op. cit. p. 257. 
conhecimento de nossos pensamentos, sentimentos, sensações e emoções. É o direito de viver em solidão aquela parte da nossa vida que não desejamos compartilhar com os demais, seja com a sociedade que nos rodeia, como todo mundo que nos circunda, seja com uma parte deste mundo. Atua este direito em relação ao Estado, no sentido de limitar a sua intervenção, e aos demais indivíduos, impondo a eles um dever de abstenção. ${ }^{26}$

Ada Pellegrini Grinover define intimidade como "a esfera de que o indivíduo necessita vitalmente para poder livre harmoniosamente desenvolver sua personalidade, ao abrigo de interferências estatais". ${ }^{27}$

A Lei Maior, ao estabelecer a distinção a que já nos referimos, levou em consideração dois aspectos da vida das pessoas: a vida exterior e pública, que envolve relações pessoais e atividades públicas e a vida interior que diz respeito à mesma pessoa, mas em relação aos membros de sua família e seus amigos, integrando esta a vida privada.

Entretanto, como bem ressaltado por José Afonso da Silva, a tutela constitucional desse direito engloba tanto o segredo como a liberdade. O primeiro, como expansão da personalidade, tem como pressuposto indispensável à liberdade do indivíduo de realizar a sua vida privada, sem interferências $^{28}$.

Este direito serviu como limite à atuação estatal em sua primeira vertente, embora com sentido conservador, como proteção dos bens do particular. Posteriormente, foi empregada como tentativa de impedir o controle ideológico por parte do estado. Hoje, com o progresso tecnológico, sobretudo no que respeita à comunicação por meio da informática, e com os abusos praticados pelo poder da imprensa e as invasões de terceiros, os contornos do direito à intimidade vêm aumentando.

\footnotetext{
${ }^{26}$ CARVALHO, Luiz Gustavo Grandinetti Castanho de. Op. cit. p. 53-55.

${ }^{27}$ GRINOVER, Ada Pellegrini. Liberdades públicas e processo penal.São Paulo: Saraiva, 1976. p. 95. Apud: CARVALHO, Luiz Gustavo Grandinetti Castanho de. Op. cit. p. 54.

${ }^{28}$ SILVA, José Afonso da. Op. cit. p. 211.
} 
“É que a vida social por si só já expõe o indivíduo à interação coletiva e, em alguma medida, à permanente transparência do exercício da personalidade, que cada vez menos experimenta o fenômeno do isolamento e da segregação". ${ }^{29}$

A honra constitui um direito independente, posto que correlato à intimidade e à vida privada, da personalidade. Corresponde ao conjunto de qualidades que caracterizam a dignidade da pessoa, a reputação e o bom nome. Não caracteriza propriamente um direito à privacidade, com este só se relacionando quando o direito à honra estiver ameaçado por algo contrário à dignidade humana que deva permanecer em segredo.

A imagem, por sua vez, consiste na defesa do aspecto físico e "satisfaz uma exigência espiritual de isolamento, uma necessidade eminentemente moral" 30 .

O Código Civil português oferece uma conceituação acerca do direito à imagem:

"Art. 79 - 1. O retrato de uma pessoa não pode ser exposto, reproduzido ou lançado no comércio sem o consentimento dela; depois da morte da pessoa retratada, a autorização compete às pessoas designadas no . $^{\circ} 2$ do at. 71 , segundo a ordem nele indicada".

2. Não é necessário o consentimento das pessoas retratadas quando assim o justifique a sua notoriedade, o cargo que desempenhem, exigências de polícia ou de justiça ou culturais ou quando a reprodução da imagem vier enquadrada na de lugares públicos ou na de fatos de interesse público ou que hajam ocorrido publicamente.

3. O retrato não pode porém ser reproduzido, exposto ou lançado no comércio se do fato resultar prejuízo para a honra, reputação ou simples decoro da pessoa retratada".

\footnotetext{
${ }^{29}$ SIQUEIRA CASTRO, Carlos Roberto. A constituição aberta e os direitos fundamentais: ensaios sobre o constitucionalismo pós moderno e comunitário. Rio de Janeiro: Forense, 2003. p. 437.

${ }^{30}$ CUPIS, Adriano de. Riservatezza e segretto (Diritto a). in Novissimo digesto italiano. Torino: UTET, 1969. p. 115. Apud: SILVA, José Afonso da. Op. cit. p. 212.
} 
Celso Ribeiro Bastos ${ }^{31}$ faz menção ao direito à reserva da privacidade, ressaltando que em determinadas situações este direito não pode ser invocado. São públicos, de livre acesso a todos, tais como restaurantes, casas noturnas, e demais locais "em que o público e o particular se entrelaçam de uma maneira quase que inextrincável”. Quem frequienta estes lugares está, antes de tudo, abrindo mão da sua privacidade, sem, contudo, chamar para si a publicidade.

Já a proteção à honra consiste, no dizer do mesmo autor, no "direito de não ser ofendido ou lesado na sua dignidade ou consideração social. Caso ocorra tal lesão, surge o direito à defesa." 32

Parte da doutrina é contrária à proteção da intimidade das pessoas jurídicas. Quem defende esta tutela, o faz em atribuição ao fato de que a divulgação de uma particularidade da vida interna de uma empresa pode acarretar lesões à sua idoneidade ou saúde financeira. ${ }^{33}$

\subsection{Liberdade de expressão e liberdade de imprensa}

Conceitualmente, poder-se-ia estabelecer, de início, entre a liberdade de expressão e a liberdade de imprensa tênues diferenças.

Para Pontes de Miranda ${ }^{34}$, a base de toda e qualquer liberdade é a liberdade psíquica, abrangendo "tudo que serve para enunciar, auxiliar os enunciados (gestos, projeções, pinturas), e dar sentido, bem como tudo que não é o movimento só ou a abstenção dele". A liberdade de emissão de pensamento, sob esta ótica, incluída a liberdade de imprensa, está

\footnotetext{
${ }^{31}$ BASTOS, Celso Ribeiro e MARTINS, Ives Gandra. Comentários à Constituição do Brasil. São Paulo: Saraiva, 1989. p. 64.

${ }^{32}$ Ibid., loc. cit.

${ }^{33}$ LEYSER, Maria de Fátima Vaquero Ramalho. Direito à liberdade de imprensa. Justitia. São Paulo, v. 63 (194), p. 87, abr.-jun. 2001.

${ }^{34}$ PONTES de MIRANDA, Francisco Cavalcanti. Comentários à Constituição de 1967 com a Emenda.$^{\circ} 1$ de 1969. vol. 5, p. 150. Apud: CARVALHO, Luiz Gustavo Grandinetti Castanho de. Op. cit. p. 39.
} 
relacionada com as demais pessoas, enquanto a liberdade de pensamento é relacionada ao homem consigo mesmo, sozinho.

Para José Afonso da Silva, outrossim, a liberdade de pensamento possui dois aspectos, de ordem interna e externa. A liberdade de pensamento se caracterizaria como "a exteriorização do pensamento no seu sentido mais abrangente. É que, no seu sentido interno como pura consciência, como pura crença, mera opinião, a liberdade de pensamento é plenamente reconhecida, mas não cria problema maior". 35

Desta liberdade surgem, então, para o autor, as formas de sua manifestação, através da liberdade de opinião, ou de suas exteriorizações pelo exercício das liberdades de comunicação, de religião, de expressão intelectual, artística, científica e cultural e de transmissão e recepção do conhecimento. A liberdade de imprensa estaria contida, segundo esta classificação, na liberdade de comunicação, no que se refere à liberdade de informação jornalística, com a qual não se confunde. Isto se dá em razão da liberdade de imprensa se resumir à publicação de veículo impresso de comunicação, enquanto a liberdade de informação jornalística, prevista no art. $220, \S 1^{\circ}$ da Constituição de 198 , alcançaria qualquer forma de difusão de notícias, comentários e opiniões por qualquer veículo de comunicação. ${ }^{36}$

São vários os meios de expressão. O homem pode exprimir-se pela fala escrita, música, artes plásticas e por outros meios que vão surgindo a cada inovação tecnológica. A comunicação social, segundo contexto da comunicação (o primeiro diz respeito à comunicação pessoal), é aquela que se utiliza dos meios de comunicação de massa, dirigindo-se a um grande números de pessoas desconhecidas do autor. ${ }^{37}$

A partir dessa forma de expressão, em função deste segundo contexto, que foi estabelecida pelo constituinte, para além da liberdade de

\footnotetext{
${ }^{35}$ SILVA, José Afonso da. Op. cit. p. 244.

${ }^{36}$ Ibid. p. 249.

${ }^{37}$ BASTOS, Celso Ribeiro. Op. cit. p. 44.
} 
expressão, a liberdade de imprensa, disciplinada no capítulo referente à comunicação social - artigos 220 a 224 da Constituição de 1988.

Apesar de inserida em um conceito amplo de liberdade de expressão, a liberdade de imprensa não possui a mesma natureza de direito fundamental individual, motivo pelo qual optou o constituinte pela separação entre os dispositivos. À imprensa cabe a "função de investigar, noticiar, denunciar e fiscalizar, desempenhando um papel de suma importância para o regime democrático. É da carta de princípios da Inter American Press Association a seguinte frase: 'sem liberdade de imprensa não há democracia'". 38

Esta liberdade constitui um direito fundamental do dono de empresa de exercer a sua atividade, mas especialmente um dever de informar à coletividade os acontecimentos e idéias de forma verídica, preservando o seu conteúdo. Não se deve ignorar que o público deve ser informado com segurança sobre a verdade dos fatos. $\mathrm{O}$ direito à informação tem um requisito essencial que se traduz na informação verídica, imparcial. Sem este pressuposto não há que se falar em caráter fundamental da liberdade de imprensa.

A liberdade de expressão, que tem, assim como a liberdade de imprensa, matriz na liberdade de manifestação de pensamento, tem sua origem no Bill of Rights inglês, de $1689{ }^{39}$. Vigorava àquela época o Licensing Act, segundo o qual era assegurada apenas a alguns a possibilidade de veicular informação através de impressos, sempre em submissão ao monarca. Com a sua abolição, em 1695, passou-se a assegurar ampla liberdade de imprimir, não obstante ainda não estivesse plenamente protegida a liberdade de pensar e exprimir-se.

Quando do Estado Absolutista, não fazia sentido defender a liberdade de expressão, com fundamento na infalibilidade do rei expressa

\footnotetext{
${ }^{38}$ BASTOS, Celso Ribeiro. Op. cit. p. 45.

39 Art. $8^{\circ}$ - "Que a liberdade de expressão no seio do Parlamento, assim como os debates ou encaminhamentos, só pelo próprio Parlamento podem ser restringidos ou questionados."
} 
na premissa the king do no wrong. A invenção da prensa provocou enorme pressão na liberação das publicações. Tanto que em 1644 John Milton publicou a Aeropagítica, considerada a primeira obra em favor da liberdade de imprensa, tendo sido dirigida ao Parlamento da Inglaterra, explicitamente tachando as restrições impostas pelo governo como obstáculos criticáveis. ${ }^{40}$

Convém citar neste momento Spinoza, para quem a liberdade de manifestação do pensamento é fundamental até mesmo para a manutenção do poder, ao contrário do que os governos totalitários sempre buscavam. Neste sentido, afirma que:

"Se se quiser, pois, que se aprecie a fidelidade e não a bajulação, se se quiser que as autoridades soberanas mantenham intacto o poder e não sejam obrigadas a fazer cedências aos revoltosos, terá obrigatoriamente de se conceder a liberdade de opinião e governar os homens de modo a que, professando embora publicamente opiniões diversas e até contrárias, vivam apesar disso em concórdia. E não há dúvida que esta maneira de governar é a melhor e a que traz menos inconvenientes, porquanto é a que mais se ajusta à natureza humana. (...) Sendo assim, quanto menos liberdade de opinião se concede aos homens, mais nos afastamos [de nosso estado natural e da forma mais natural de governo [a democracia], e, por conseguinte, mais violento é o poder] ${ }^{41}$

Posteriormente, merece registro On Liberty, de John Stuart Mill, obra na qual define quatro razões para a defesa da liberdade de expressão como meio da busca pela verdade. A primeira delas seria porque uma opinião reduzida ao silêncio pode ser verdade; a segunda, pois, embora a opinião emitida esteja errada, pode conter algo de correto; a terceira porque sendo a opinião geral totalmente verdadeira, a crítica séria e enérgica poderá servir para a compreensão de seus fundamentos racionais; por fim, a

\footnotetext{
${ }^{40}$ SANCHEZ GONZALES, Santiago. Lá liberdad de expresión. Madrid: Marcial Pons, 1992. p. 22-23. Apud: FONTES JÚNIOR, João Bosco Araújo. Liberdades e limites na atividade de rádio e televisão: teoria geral da comunicação social na ordem jurídica brasileira e no direito comparado. Belo Horizonte: Del Rey, 2001. p. 35.

${ }^{41}$ Tratado teológico-político. Trad. Diogo Pires Aurélio. Lisboa, Imprensa Nacional-Casa da Moeda, 1988. cap. 20, p. 371. Apud: CHAUí, Marilena de Souza. Espinosa: uma filosofia da liberdade. São Paulo: Moderna, 1995. p. 101-103.
} 
transformação da convicção da verdade em dogma impede o desenvolvimento de outras convicções. ${ }^{42}$

Registre-se, ainda, a tese de Thomas Emerson, responsável por construir a primeira teoria neste âmbito, adaptada às exigências do mundo intercomunicado em que vivemos, considerando os direitos de se formar, de possuir as próprias crenças e comunicá-las por quaisquer meios, passando pelos direitos de investigação, de informação até os direitos de reunião e associação, corolário imprescindível da liberdade de expressão. ${ }^{43}$

Sob este prisma, o Estado deve, além de garantir a liberdade negativa, fomentar a livre expressão, fornecendo os meios materiais e informação, removendo os empecilhos e coibindo as distorções, "podendo chegar a intervir com rigor para assegurar o exercício deste direito no seio das grandes e poderosas organizações privadas"

"A liberdade de expressão consiste, pois, no direito de exprimir e divulgar livremente o seu pensamento. É direito de não ser impedido de exprimir-se. Ao titular da liberdade de expressão é conferido o poder de agir, pelo qual contará com a abstenção ou não interferência de quem quer que seja no exercício do seu direito". 45

Para Flávia Viveiros de Castro, a liberdade de expressão, assim tida como um direito da personalidade, é fundamental para a materialização do princípio da dignidade da pessoa humana, dimensão individual esta que é preponderante, mas não única.

Acrescenta a autora que o direito a esta liberdade determina funções específicas para quem o incorpora e para a sociedade que dele se beneficia. É, assim, percebida a liberdade de expressão não somente em

\footnotetext{
${ }^{42}$ FONTES JÚNIOR, João Bosco Araújo. Op. cit. p. 36.

${ }^{43}$ Ibid. p. 37.

${ }^{44}$ Ibid., loc. cit.

45 BASTOS, Celso Ribeiro. Os limites à liberdade de expressão na Constituição da República. Revista Forense. Rio de Janeiro, v. 349, p. 44, 2000.
} 
relação ao indivíduo que a exerce, mas em interdependência com a sua funcionalidade, que guarda inegável aspecto social.

A mesma autora traz a classificação doutrinária do direito à liberdade de expressão como liberdade e garantia, advertindo, com apoio em Canotilho, "que se trata de classificação relevante sob diversos pontos de vista: a uma porque pressupõe regime jurídico-constitucional especial a duas (sic.), pois serve de parâmetro material a direitos análogos espalhados pelo texto constitucional e a três porque a ele o texto constitucional atribui força vinculante e densidade aplicativa próprias". 46

No Estado Social, em função da mudança na própria concepção dos direitos fundamentais, que passam a ser dotados também em uma perspectiva social, percebe-se uma profunda alteração em seu conteúdo, posto que mantendo o fundamento nas liberdades clássicas do liberalismo, passa a compreender uma dimensão objetiva, visando a assegurar a fruição das liberdades por todos.

A liberdade de expressão deixa completamente de ser uma mera abstenção do Estado para dar espaço à função social desta liberdade, necessária para a formação da opinião pública livre.

Desta feita, a doutrina vem reconsiderando a liberdade de expressão, para convertê-la em uma liberdade de opinião pública, como base da democracia. ${ }^{47}$ A liberdade de expressão, sob essa nova dimensão participativa e pluralista, não é fundada somente na liberdade, mas nos valores fundamentais da igualdade e dignidade da pessoa humana.

Ensina, a esse respeito, Rafael Bielsa, que:

\footnotetext{
${ }^{46}$ CASTRO, Flávia Viveiros de. A liberdade de expressão no contexto dos direitos fundamentais, a responsabilidade da imprensa $e$ os tribunais. Disponível em: $<$ http://www.mundojuridico.adv.br>. Acesso em: 30 mar. 2005.

${ }^{47}$ SOLOZABAL ECHEVARRIA, Juan José. Aspectos constitucionales de la libertad de expresión y el derecho a la información. Revista Española de Derecho Constitucional, p. 145, ano 8, n. ${ }^{\circ} 23$, mayo/ago. 1988, Madrid. PEREIRA, Fernando José Correia. Liberdade de expressão fundamentos e limites. Revista Tribunal da Justiça, n. ${ }^{\circ}$ 41/42, p. 10, maio/jun. 1988, Lisboa. CANOTILHO, José Joaquim Gomes; MOREIRA, Vital. Constituição portuguesa anotada. 3. Ed. Coimbra: Coimbra Editora, 1996. p. 230. Apud: FONTES JÚNIOR, João Bosco Araújo. Op. cit. p. 43
} 
"Por grande e benéfica que seja a ação orientadora da opinião pública, para a informação e a crítica, a liberdade de imprensa, como toda a liberdade, tem suas limitações virtuais e necessárias nas outras liberdades, e nos direitos privados e públicos. Se essa liberdade é desenfreada, e afeta a honra, o bom nome e o crédito das pessoas, falseando ou tergiversando a verdade dos fatos (ainda quando eles sejam certos e se trate de ações privadas), é evidente que não só se lhe deve negar proteção, mas também reprimir seus excessos antijurídicos e anti-sociais. É que a má imprensa não só lesa direitos e interesses jurídicos e morais das pessoas a quem afeta a publicidade caluniadora ou escandalosa, como também corrompe, progressivamente, sentimentos de moralidade média da sociedade, engendra uma espécie de curiosidade e animosidade mórbidas no público, e, sobretudo, nas pessoas que, por falta de sentido crítico, de reflexão ou de experiência são propensas às vias de fato, perigo que comprova a psicologia das multidões. Para sorte da moralidade pública, o pasquim tende a desaparecer e com ele seus gestores, às vezes sob a férula judicial."48

Assim, percebe-se o duplo sentido da liberdade de expressão, um ligado ao caráter individual e pessoal e outro fundado nas relações sociais, na prevalência do interesse público. Em razão desta constatação, adere à liberdade de expressão a liberdade de imprensa.

Novamente citando Canotilho, Flávia Viveiros de Castro traz apontamentos sobre as funções precípuas dos direitos fundamentais, quais sejam, a prestacional relativa ao acesso garantido pelo Estado à informação; a protetiva perante terceiros, devendo o Estado adotar medidas positivas, assegurando o exercício dos direitos fundamentais de caráter individual, e, por fim, a função de não discriminação, com arrimo no direito à isonomia, orientando a atividade estatal a oferecer igual oportunidade de acesso à informação. ${ }^{49}$

A Declaração dos Direitos do Homem e do Cidadão, de $1789^{50}$, conquanto não estabelecesse verdadeiras imposições jurídicas - assim como

\footnotetext{
${ }^{48}$ BIELSA, Rafael. Estudios de Derecho Público. Buenos Aires: Depalma, 1950, vol. III, p. 733. Apud: MIRANDA, Darcy de Arruda. Comentários à lei de imprensa. $3^{\mathrm{a}}$ ed. São Paulo: Revista dos Tribunais, 1995. p. 66.

${ }^{49}$ CASTRO, Flávia Viveiros de. Op. cit.
} 
a atual Declaração Universal de Direitos Humanos da Organização das Nações Unidas, de 10 de dezembro de $1948^{51}$-, explicitou princípios, diretrizes, para as democracias modernas, dentre os quais a liberdade de manifestação do pensamento, primeiramente em seu sentido puramente negativo, "garantindo o cidadão em face das ingerências do Estado na esfera da sua liberdade de divulgar suas idéias, perfeitamente compreensível no contexto histórico do liberalismo, em seguimento à mais conhecida Revolução Liberal da História" 52.

A partir da Declaração Universal dos Direitos Humanos, de 1948, a liberdade de expressão passa a ser concebida pressupondo o direito à informação.

\section{O artigo 19 do Pacto Internacional sobre Direitos Civis e} Políticos contempla a liberdade de expressão e o direito de procurar, receber e difundir informações por qualquer meio da sua escolha, prevendo no artigo subsequente a possibilidade de sua restrição. ${ }^{53}$

A Convenção Européia dos Direitos do Homem incluiu na garantia prevista no artigo 10 o direito ao acesso à informação, além de restrições ao abuso desta liberdade, permitindo a adoção de medidas restritivas, desde que previstas em lei e necessárias para assegurar o

\footnotetext{
${ }^{50}$ Art. XI - "A livre comunicação do pensamento e da opinião é um dos direitos mais preciosos do homem: todo cidadão pode pois falar, escrever, imprimir livremente, salvo quando tiver que responder ao abuso desta liberdade, nos casos previstos em lei".

${ }^{51}$ Art. XIX - "Toda pessoa tem direito à liberdade de opinião e expressão; este direito inclui a liberdade de, sem interferência, ter opiniões e de procurar, receber e transmitir informações e idéias por quaisquer meios e independentemente de fronteiras."

${ }^{52}$ FONTES JÚNIOR, João Bosco Araújo. Op. cit. p. 40.

53 Art. 19 - "1. Ninguém poderá ser molestado por suas opiniões.

2. Toda pessoa terá direito à liberdade de expressão; esse direito incluirá a liberdade de procurar, receber e difundir informações e idéias de qualquer natureza, independentemente de considerações de fronteiras, verbalmente ou por escrito, em forma impressa ou artística, ou qualquer outro meio de sua escolha.

3. O exercício do direito previsto no $\S 2^{\circ}$ do presente artigo implicará deveres e responsabilidades especiais.

Conseqüientemente, poderá estar sujeito a certas restrições, que devem, entretanto, ser expressamente previstas em lei e que se façam necessárias para:

a) assegurar o respeito dos direitos e da reputação das demais pessoas;

b) proteger a segurança nacional, a ordem, a saúde ou a moral pública."

"Art. 20 - 1. Será proibida por lei qualquer propaganda em favor de guerra.

2. Será proibida por lei qualquer apologia do ódio nacional, radical, racial ou religioso que constitua incitamento à discriminação, à hostilidade ou à violência."
} 
respeito aos direitos e reputação das demais pessoas e a segurança nacional, a ordem, a saúde ou moral públicas. ${ }^{54}$

Por seu turno, a Convenção Americana sobre Direitos Humanos, além de assegurar os direitos já mencionados, considerou ilegítima a sua restrição por meios indiretos, como o abuso dos controles oficiais sobre quaisquer meios destinados à comunicação e circulação de idéias e opinião. ${ }^{55}$

Pode-se observar que nessas Declarações e Pactos Internacionais é perfeitamente possível, sem constituir afronta alguma, estabelecer regulamentação para a liberdade em análise, desde que mediante lei.

A primeira Constituição a prever esta liberdade, com base na Declaração dos Direitos do Homem e do Cidadão, foi a norte-americana,

\footnotetext{
${ }^{54}$ Art. 10 - "1. Toda persona tiene derecho a la libertad de expresión. Este derecho comprende la libertad de opinión y la libertad de recibir o de comunicar informaciones o ideas sin que pueda haber injerencia de autoridades públicas y sin consideración de fronteras. El presente artículo no impide que los Estados sometan a las empresas de radiodifusión, de cinematografía o de televisión a un régimen de autorización previa.

2. El ejercicio de estas libertades que entrañan deberes y responsabilidades, podrá ser sometido a ciertas formalidades, condiciones, restricciones o sanciones previstas por la ley, que constituyan medidas necesarias, en una sociedad democrática, para la seguridad nacional, la integridad territorial o la seguridad pública, la defensa del orden e la prevención del delito, la protección de la salud o de la moral, la protección de la reputación o de los derechos ajenos, para impedir la divulgación de informaciones confidenciales o para garantizar la autoridad y la imparcialidad del poder judicial."

${ }_{55}$ Art. 13 - "1. Toda pessoa tem direito à liberdade de pensamento e de expressão. Esse direito compreende a liberdade de buscar, receber e difundir informações e idéias de toda natureza, sem consideração de fronteiras, verbalmente ou por escrito, ou em forma impressa ou artística, ou por qualquer outro processo de sua escolha".

2. O exercício do direito previsto no inciso precedente não pode estar sujeito a censura prévia, mas a responsabilidades ulteriores, que devem ser expressamente fixadas pela lei a ser necessárias para assegurar:

a) o respeito aos direitos ou à reputação das demais pessoas; ou

b) a proteção da segurança nacional, da ordem pública, ou da saúde ou da moral públicas. 3. Não se pode restringir o direito de expressão por vias ou meios indiretos, tais como o abuso de controles oficiais ou particulares de papel de imprensa, de freqüências radioelétricas ou de equipamentos e aparelhos usados na difusão de informação, nem por quaisquer outros meios destinados a obstar a comunicação e a circulação de idéias e opiniões.

4. A lei pode submeter os espetáculos públicos a censura prévia, com o objetivo exclusivo de regular o acesso a eles, para proteção moral da infância e da adolescência, sem prejuízo do disposto do inciso 2.

5. A lei deve proibir toda propaganda a favor da guerra, bem como toda apologia ao ódio nacional, racial ou religioso que constitua incitação à discriminação, à hostilidade, ao crime ou à violência."
} 
com a $1^{\mathrm{a}}$ Emenda à Constituição dos Estados Unidos de 1789, ratificada em $1791^{56}$. No Brasil, na época colonial, era total a proibição de imprimir.

Em 1808 suspendeu-se a proibição à prensa, muito embora não existisse no país a livre atividade de imprensa. Neste ano surgiu o primeiro jornal no Brasil, “A Gazeta do Rio de Janeiro”, submetido à censura prévia.

A Constituição de 1824 passou a estabelecer a liberdade de manifestação do pensamento:

"Art. 179. A inviolabilidade dos direitos civis e políticos dos cidadãos brasileiros, que tem por base a liberdade, a segurança individual e a propriedade, é garantida pela Constituição do Império, pela seguinte maneira:

$[\ldots]$

IV. Todos podem comunicar seus pensamentos, por palavras, escritos, e publicá-los pela imprensa, sem dependência de censura, contanto que hajam de responder pelos abusos que cometerem no exercício deste direito, nos casos e pela forma que a lei determinar."

Na Constituição de 1891, a mesma liberdade era assegurada, acrescentando-se a vedação ao anonimato. ${ }^{57}$

O artigo 113, n. 9, da Constituição de 1934, assegurou a livre manifestação de pensamento, mas previu a possibilidade de censura em relação a espetáculos e diversões públicas ${ }^{58}$.

\footnotetext{
56 "O Congresso não deve editar nenhuma lei estabelecendo uma religião oficial para o Estado, ou proibindo o pleno exercício da liberdade de crença; ou limitando a liberdade de expressão, ou de imprensa; ou o direito das pessoas se reunirem pacificamente, e de dirigirem petição ao governo para retificar abuso."

${ }^{57}$ Art. 72, §12 - "Em qualquer assunto é livre a manifestação do pensamento pela imprensa, ou pela tribuna, sem dependência de censura, respondendo cada um pelos abusos que cometer, nos casos e pela forma que a lei determinar. Não é permitido o anonimato".

58 "Em qualquer assunto é livre a manifestação de pensamento, sem dependência de censura, salvo quanto a espetáculos e diversões públicas, respondendo cada um pelos abusos que cometer, nos casos e pela forma que a lei determinar. Não é permitido o anonimato. É assegurado o direito de resposta. A publicação de livros e periódicos independe de licença do poder público. Não será, porém, tolerada propaganda de guerra ou de processos violentos para subverter a ordem política ou social".
} 
A Constituição de 1937 estabeleceu uma série de condições para o exercício da liberdade de expressão, próprios do regime em que foi elaborada ${ }^{59}$, não deixando essa questão para o legislador ordinário.

Repetindo a previsão constitucional anterior ao Estado Novo, a Constituição de 1946 afastou os óbices impostos pela Constituição de 1937, apenas trazendo as mesmas restrições no que respeita aos espetáculos e diversões públicas.

A Constituição de 1967, posto que tenha previsto a liberdade de imprensa, trouxe a possibilidade de restrições por parte do Supremo Tribunal Federal, podendo suspender "os direitos políticos daquele que 'abusar' das liberdades de expressão, de reunião e de associação" "60, na forma dos artigos 150 e 151:

“Art. 150, $\$ \mathbf{8}^{\mathbf{0}}$ - É livre a manifestação de pensamento, de convicção política ou filosófica e a prestação de informação sem sujeição à censura, salvo quanto a espetáculos de diversões públicas, respondendo cada um, nos termos da lei, pelos abusos que cometer. É assegurado o direito de resposta. A publicação de livros, jornais e periódicos independe de licença da autoridade. Não será, porém, tolerada a propaganda de guerra, de subversão da ordem ou de preconceitos de raça ou de classe."

\footnotetext{
59 "Todo cidadão tem o direito de manifestar o seu pensamento, oralmente, ou por escrito, impresso ou por imagens, mediante as condições e nos limites prescritos em lei. A lei pode prescrever: a) com o fim de garantir a paz, a ordem e a segurança pública, a censura prévia da imprensa, do teatro, do cinematógrafo, da radiodifusão, facultando à autoridade competente proibir a circulação, a difusão ou a representação; b) medidas para impedir as manifestações contrárias à moralidade pública e aos bons costumes, assim como as especialmente destinadas à proteção da infância e da juventude; c) providências destinadas à proteção do interesse público, bem-estar do povo e segurança do Estado. A imprensa regular-se-á por lei especial, de acordo com os seguintes princípios: a) a imprensa exerce uma função de caráter público; b) nenhum jornal pode recusar a inserção de comunicados do Governo, nas dimensões taxadas em lei; c) é assegurado a todo cidadão o direito de fazer inserir gratuitamente, nos jornais que o infamarem ou injuriarem, resposta, defesa ou retificação; d) é proibido o anonimato; e) a responsabilidade se tornará efetiva por pena de prisão contra o diretor responsável e pena pecuniária aplicada à empresa; f) as máquinas, caracteres e outros objetos tipográficos utilizados na impressão do jornal constituem garantia do pagamento da multa, reparação ou indenização e das despesas com o processo nas condenações pronunciadas por delito de imprensa, excluídos os privilégios eventuais derivados do contrato de trabalho da empresa jornalística com os seus empregados. A garantia poderá ser substituída por uma caução depositada no princípio de cada ano e arbitrada pela autoridade competente, de acordo com a natureza, a importância e a circulação do jornal; g) no podem ser proprietários de empresas jornalísticas as sociedades por ações ao portador e os estrangeiros, vedado tanto a estes como às pessoas jurídicas participar de tais empresas como acionistas. A direção dos jornais, bem como a sua orientação intelectual, política e administrativa, só poderá ser exercida por brasileiros natos."

60. PILATTI, Adriano. Formação Constitucional do Brasil. Mimeo. p. 26
} 
"Art. 151 - Aquele que abusar dos direitos individuais previstos nos $\S \S 8^{\circ}, 23.27$ e 28 do artigo anterior e dos direitos políticos, para atentar contra a ordem democrática ou praticar a corrupção, incorrerá na suspensão destes últimos direitos pelo prazo de dois a dez anos, declarada pelo Supremo Tribunal Federal, mediante representação do Procurador-Geral da República, sem prejuízo da ação civil ou penal cabível, assegurada ao paciente a mais ampla, defesa."

O Ato Institucional n. ${ }^{\circ}$ 05, de 1968, suprimiu, durante a sua vigência, a liberdade de expressão, visto que o Presidente "podia instituir a censura prévia sobre os meios de comunicação e as atividades artísticas"61.

A Emenda Constitucional n. ${ }^{\circ} 1$ de 1969, reiterou a vigência do Ato n. ${ }^{\circ}$ 5, que só veio a ser revogado em 1978, com a aprovação pelo Congresso Nacional da Emenda n. ${ }^{\circ} 11 .{ }^{62}$

A Lei n. ${ }^{\circ}$ 5250, de 9 de fevereiro de 1967, revogando a Lei n. ${ }^{\circ}$ 2083, de 12 de novembro de 1953, regulou, além da liberdade de imprensa, a liberdade de manifestação do pensamento e da informação, ainda sob a vigência do AI-5, que só foi revogado em 13 de outubro de 1978, com a Emenda n. ${ }^{\circ} 11$. O projeto da nova Lei de Imprensa - PLS n. ${ }^{\circ} 3232$, de 1992, do Senado Federal - consagra o direito à liberdade de imprensa, sem censura prévia.

A Constituição de 1988 restaurou a liberdade de expressão, mais especificamente a liberdade de comunicação social, na sua plenitude, conforme analisaremos a seguir, nos termos do artigo $5^{\circ}$, inciso IX, e 220, in verbis:

"Art. 5', IX - é livre a expressão da atividade intelectual, artística, científica e de comunicação social, independentemente de censura ou licença."

“Art. 220 - A manifestação de pensamento, a criação, a expressão e a informação, sob qualquer forma, processo ou veículo, não sofrerão qualquer restrição, observado o disposto nesta Constituição.

\footnotetext{
${ }^{61}$ PILATTI, Adriano. Op. cit. p. 27.

${ }^{62}$ Ibid. p. 29.
} 
$\S \mathbf{1}^{\mathbf{0}}$ - Nenhuma lei conterá dispositivo que possa constituir embaraço à plena liberdade de informação jornalística em qualquer veículo de comunicação social, observado o disposto no art. $5^{\circ}$, IV, $\mathrm{V}, \mathrm{X}, \mathrm{XIII}$ e XIV.

$\$ \mathbf{2}^{\mathbf{0}}$ - É vedada toda e qualquer censura de natureza política, ideológica e artística.

$[\ldots] "$

Ao passo que a limitação à liberdade de comunicação jornalística "guarda perfeita consonância com a clássica definição de que os direitos fundamentais não são absolutos" ${ }^{63}$, devendo ser exercida em harmonia com os demais direitos, não excluindo a Constituição de 1988 a sua possibilidade, passaremos a analisar a colisão entre a liberdade de imprensa e o direito à intimidade, já que como bem suscitado por Gilmar Ferreira Mendes ${ }^{64}$ :

“... como diria o Conselheiro Acácio, aquilo que é inviolável não pode ser violado. Mas ainda. Se a Constituição assegura não só a inviolabilidade do direito, mas também a efetiva proteção judiciária contra a lesão ou ameaça de lesão a direito (CF, art. $\left.5^{\circ}, \mathrm{XXXV}\right)$, não poderia o Judiciário intervir para obstar a configuração da ofensa definitiva, que acaba acarretando danos irreparáveis? Que significaria a garantia de proteção judiciária efetiva contra lesão ou ameaça a direito se a intervenção somente pudesse se dar após a configuração da lesão? Pouco, certamente muito pouco!".

\footnotetext{
${ }^{63}$ BASTOS, Celso Ribeiro. Op. cit. p. 47.

${ }^{64}$ Ibid. p. 46.
} 


\section{Conflitos e soluções}

Os direitos fundamentais não são absolutos nem ilimitados. Isto se dá em função da "multiplicidade de aspectos e projeções valorativas dos direitos humanos que pode levar à situação de aparente conflito, imprimindo a necessidade de opção", ou desafiando "outros 'valores' da vida em sociedade, colocando um ponto de interrogação sobre a prevalência que se deva conferir ao direito fundamental ou aos valores-princípios em questão". 65

Sobre este assunto, Jorge Miranda ${ }^{66}$ tratou de fixar os conceitos de restrição, limite, condicionamento, regulamentação e suspensão de direitos. Restrição diz respeito ao direito em si e sua extensão objetiva, envolvendo a amputação de faculdades que a priori estariam nele contidas, atingindo o direito de forma permanente e sempre parcial. Os limites afetam o exercício do direito e sua manifestação e referem-se a quaisquer direitos, já que fundados em razões de caráter geral (v.g. moral, bem estar social, etc.). Podem resultar em um condicionamento, representando "um segmento de natureza cautelar de que se faz depender o exercício de algum direito", não reduzindo o seu âmbito, "implicando ou disciplinando limitação do exercício de uma liberdade ou de um ônus". A regulamentação baseia-se no "preenchimento ou desenvolvimento legislativo do conteúdo do direito, classificando-o, determinando-o" ou ampliando-o, nunca o diminuindo. Por fim, a suspensão atinge de forma transitória o direito, "paralisando ou impedindo seu exercício, total ou parcialmente", podendo ainda haver, neste caso, uma concordância com a restrição.

Desta forma, há, na Constituição, normas de índole principiológica que, assim como as demais nela contidas, podem entrar em

\footnotetext{
${ }^{65}$ SAMPAIO, José Adércio Leite. Direito à intimidade e à vida privada: uma visão jurídica da sexualidade, da família, da comunicação e informações pessoais, da vida e da morte. Belo Horizonte: Del Rey, 1998. p. 379-380.

${ }^{66}$ Acerca da Teoria Geral dos limites dos direitos fundamentais: MIRANDA, Jorge. Op. cit. p. 297-299. Apud: SAMPAIO, José Adércio Leite. Op. cit. p. 379 (nota).
} 
conflito com outras normas de natureza semelhante. É o caso da liberdade de expressão ou do direito à informação, de um lado, e o direito à intimidade, à vida privada, à imagem e à honra, de outro.

Isso ocorre, como já vimos, pois tutelam diferentes direitos, ainda que inerentes a todos os seres humanos, já que, ao passo que todos têm direito a obter informações dos meios de comunicação, aqueles de quem se busca a "notícia", em tese, podem manter preservados seus direitos da personalidade, assim entendidos como os "que constituem o minimum necessário e imprescindível ao conteúdo da personalidade, sendo próprios da pessoa em si, como ente humano, existentes desde o seu nascimento"67.

Assim sendo, "consciente de que a radiodifusão é atividade complexa e capaz de comumente atingir outros valores constitucionais, tratou o constituinte de estabelecer os limites à programação de radiodifusão, visando salvaguardar, com parâmetro na tábua de valores constitucionais, todos os direitos eventualmente em conflito". ${ }^{68}$

Entretanto, a Constituição não estabeleceu uma "cláusula geral" de forma a possibilitar que o exercício de certos direitos fundamentais fosse restringido. "Por conta disso, toda e qualquer restrição há de ser prevista de forma expressa ou decorrer diretamente dos princípios e regras adotadas pela Constituição". Essa restrição pode se dar mediante a reserva de lei restritiva (como o que ocorre na inviolabilidade das comunicações telefônicas), ou através de um direito, também fundamental, cujo exercício inviabilize o exercício de outro direito. ${ }^{69}$

Merece destaque a posição de Luiz Gustavo Grandinetti Castanho de Carvalho, para quem somente a Constituição poderá estabelecer limites à liberdade de informação, não estando o legislador

\footnotetext{
${ }^{67}$ BITTAR, Carlos Alberto. Os direitos da personalidade. Rio de Janeiro: Forense Universitária, 1989. Apud: FARIAS, Edilsom Pereira de. Od. Cit. p. 131-132.

${ }^{68}$ FONTES JÚNIOR, João Bosco Araújo. Op. cit. p. 85-86.

${ }^{69}$ LEONCY, Léo Ferreira. Colisão de direitos fundamentais a partir da Lei 6.015/97: o direito à imagem de presos, vítimas e testemunhas e à liberdade de expressão e de informação. Revista de Direito Constitucional e Internacional. São Paulo, n. ${ }^{\circ}$ 37, p. 276, out.- dez. 2001.
} 
ordinário autorizado a impor outras limitações, mediante o estabelecimento de outros direitos fundamentais. ${ }^{70}$

A repercussão coletiva conferida ao direito-dever de informar pode por vezes conduzir à aparência de que seja um direito ilimitado.

No entanto, só se poderá falar em prevalência - não em ilimitabilidade - da liberdade de informação quando a notícia veiculada contiver acontecimento, fato ou situação que tenham objetivamente transcendência pública ou relevância social, transmitida de maneira séria e medida, ou seja, a conduta jornalística não pode transpor os limites do razoável $^{71}$, não pode apresentar incidência pessoal, de modo a enfatizar o ponto de vista do próprio jornalista, mas sim com contraposição de opiniões $^{72}$ ou com veracidade na exposição completa dos acontecimentos.

"Com efeito, esta liberdade com regras, portanto sem caráter absoluto, há de ser compreendida diante de outras liberdades, em especial a privacidade das pessoas, como direito aglutinador de vários direitos concernentes à dignidade, honra e imagem das pessoas." 73

Assim, as pessoas guardam parcela de suas vidas íntimas separadas do convívio social, de tal modo que "os fatos e expressões da vida humana não estão sujeitos ao princípio dogmático da revelação

\footnotetext{
${ }^{70}$ CARVALHO, Luiz Gustavo Grandinetti Castanho de. Op. cit. p. 51.

71 "Emissora de televisão que realiza cobertura jornalística, levando ao ar cenas de suicídio mostrado ao vivo; e, logo após, seus repórteres conduzem os pais da vítima ao distrito policial para, assim, registrar, também, imagens com reações e impressões dos mesmos naquele momento de desespero, e ainda, no dia seguinte, contra a vontade dos familiares da vítima, filma, à distância, cenas do sepultamento, acompanhadas de comentários de que a menor era viciada em drogas, tudo levado ao ar em busca de alguns pontos a mais nos índices de audiência, o que sem dúvida provocou um agravamento na dor espiritual dos pais da vítima. Inegável, assim, que a emissora de TV abusou da liberdade de imprensa, princípio constitucional que deve ser exercido com consciência e responsabilidade, em respeito a outros valores igualmente importantes e protegidos pelo mesmo texto constitucional, quais sejam, a intimidade, a vida privada, a honra e a imagem das pessoas, em suma, a dignidade da pessoa humana..." Tribunal de Justiça de São Paulo. Apelação Cível n. ${ }^{\circ}$ 252.801-1/3. Rel. Des. Ricardo Feitosa. RT v. 734, p. 123.

72 "A utilização de linguajar jornalístico apropriado a uma ênfase na exposição de um ponto de vista, com relação à atividade da empresa, sem alusão pessoal, não traduz abuso de poder da imprensa...” Tribunal de Justiça de São Paulo. Apelação Cível n. ${ }^{\circ}$ 232.167-1/2. Rel. Des. Walter Theodósio. RT v. 728, p. 225.

${ }^{73}$ CASTRO, Honildo Amaral de Mello. Poder judiciário e imprensa: visão, realidade e prospectiva. Revista Brasileira de Direito Constitucional e Internacional. São Paulo, ano 10, n. ${ }^{\circ}$ 40, p. 212, jul.- set. 2002.
} 
absoluta, ou seja, a uma irrefutable disclosure, segundo a nomenclatura norte-americana, mas encontrando limites demarcatórios que preservam os segredos nucleares do ser privado, e até mesmo das pessoas jurídicas, do assédio expansionista do conhecimento público." 74

Aqui cabe, a propósito, mencionar a discussão acerca da possibilidade de proteção à intimidade das pessoas jurídicas. Há quem entenda que estas pessoas, tendo em vista a não vedação expressa da Constituição da tutela deste direito, podem ser destinatárias desta proteção jurídica, aliada à tendência universal de assegurar a esses entes, como ocorre com os seres naturais, "os prolongamentos conseqüentes da personalidade reconhecida pela legislação civil, comercial e societária, dentre as quais se inscreve, além do nome ou da razão social, dos símbolos e marcas de identificação, da imagem comercial e dos demais caracteres da personalidade jurídica, uma esfera privativa legalmente resguardada contra a intromissão de terceiros". 75

Adverte, contudo, Siqueira Castro, que "é compreensível que essa proteção constitucional e legal à privacidade das pessoas jurídicas não possui a mesma dimensão quando se cuida dos órgãos e entidades integrantes da administração estatal" ${ }^{, 76}$, em razão do principio da publicidade, informativo daquela atividade, previsto no artigo 37 caput da Constituição.

É curial neste momento trazer breve remissão às teorias aventadas acerca da possibilidade de limitação dos direitos fundamentais.

Sobre este assunto, Ignácio de Otto y Pardo baseia-se em decisões da Corte Constitucional da Espanha, com fortes influências da doutrina alemã, assentando-a, basicamente, em dois princípios: o que diz respeito à amplitude da limitação conferida pela Constituição ao legislador, aplicando-se não somente ao bem a que alude, mas também permitindo a

\footnotetext{
${ }^{74}$ SIQUEIRA CASTRO, Carlos Roberto. Op. cit. p. 532.

${ }^{75}$ Ibid. p. 536-537.

${ }^{76}$ Ibid. p. 538.
} 
imposição de outras restrições, desde que justificadas pela proteção dos demais direitos fundamentais e bens constitucionalmente reconhecidos, e o que consagra que os direitos reconhecidos sem previsão constitucional de limitação são também limitáveis, desde que seja demonstrada a necessidade de preservar outros bens constitucionalmente reconhecidos. ${ }^{77}$

Em função desta teoria, a Corte Espanhola acolheu o método da ponderação de bens, com base na teoria dos limites imanentes dos direitos fundamentais, a qual pretende decidir em que medida o direito fundamental deve ceder quando em conflito com outro direito fundamental ou com outro bem de estatura constitucional.

Ainda que sua posição tenha sido determinante para o fortalecimento daquela teoria, o autor critica a ponderação de bens. Para tanto, "sugere sejam abandonadas as intermináveis controvérsias doutrinárias, para buscar na delimitação constitucional, ou seja, na exata interpretação da Constituição, a limitação para os direitos fundamentais, lecionando, ainda, que a ponderação de bens não é o método para estabelecer qual o bem mais valioso, mas para estabelecer se a restrição ao direito fundamental, em razão de um bem constitucional, é adequada, e se sua constitucionalidade se traduz em autorização legal para limitar o direito fundamental." 78

Para o autor, destarte, haveria um espaço entre a definição abstrata do direito e a construção dogmática, no qual o legislador poderia graduar a proteção de condutas, determinando em que princípio caberiam na definição abstrata ou excluindo-as. Tal conclusão, contudo, é refutada por Grandinetti Castanho de Carvalho, que defende ser indispensável a delimitação do direito fundamental, estabelecendo-se, primeiramente, seu alcance, conteúdo, para depois examinar a necessidade ou não de restrição a partir da ponderação dos valores em choque.

\footnotetext{
${ }^{77}$ PARDO, Ignácio de Otto y e BAQUER, Lorenzo Martín-Retortillo. Derechos fundamentales y Constituición. Madri: Civitas, 1988. Apud: CARVALHO, Luiz Gustavo Grandinetti Castanho de. Op. cit. p. 40-41.
} 
Como se disse, a jurisprudência do Tribunal Constitucional Federal da Alemanha exerceu grande influência sobre neste método, na busca de "atenuar as críticas ao subjetivismo do julgador ou a despositivação do sistema, supostamente provocadas pela adoção da ponderação de bens". 79

Nesse sentido, o Tribunal passou a utilizar a ponderação com arrimo na proporcionalidade, no meio mais idôneo (ou da menor restrição possível) e da adequação entre o meio escolhido e o fim pretendido, segundo Karl Larenz" para quem "a ponderação de bens não é simplesmente matéria do sentimento jurídico, é um processo racional que não há de fazer-se, em absoluto, unilateralmente, mas que, pelo menos até certo grau, segue princípios identificáveis e, nessa medida, é também comprovável."

Em função deste entendimento já assentado pela doutrina alemã, Daniel Sarmento ${ }^{81}$ alertou que, antes da confrontação destes dois bens constitucionais, seria necessário estabelecer os limites imanentes dos direitos fundamentais em choque, alicerçada no método da ponderação de interesses. No caso concreto, após estabelecidos aqueles limites, pondera-se cada interesse em conflito com base no peso genérico - sentido geral e abstrato do princípio - e no peso específico - caso concreto, valor que se deve dar naquela hipótese, de tal forma que: “a) a restrição a cada um dos interesses deve ser idônea para garantir a sobrevivência do outro; b) tal restrição deve ser a menor possível para a proteção do interesse contraposto e c) o benefício logrado com a restrição a um interesse tem de compensar o grau de sacrifício imposto ao interesse antagônico." 82

\footnotetext{
${ }^{78}$ CARVALHO, Luiz Gustavo Grandinetti Castanho de. Op. cit. p. 41.

79 Ibid. p. 42.

80 LARENZ, Karl. Metodologia da ciência do direito. $3^{\mathrm{a}}$ ed. Lisboa: Fundação Calouste Gulbenkian, 1997. p. 574-587. Apud: CARVALHO, Luiz Gustavo Grandinetti Castanho de. Op. cit. p. 442-43

${ }^{81}$ SARMENTO, Daniel. A ponderação de interesses na constituição federal. $1^{\mathrm{a}}$ ed. Rio de Janeiro: Lumen Juris, 2002. p. 100.

82 Ibid. p. 104-105.
} 
Mas este não é o único marco teórico que apresentou alternativas à questão da possibilidade de limitação ou restrição dos direitos fundamentais. Como visto, poder-se-iam realizar:

a) através do conceito de limites imanentes e da concepção de tipificação normativa genérica reduzida, certos modos de exercício seriam excluídos do âmbito de proteção normativa. Esta teoria sofreu muitas críticas por não possuir base constitucional, "colocando os direitos fundamentais nas mãos do legislador";

b) através da justificação da restrição, resultando na teoria do núcleo essencial;

c) mediante interpretação sistemática e unitária (Ignácio de Otto y Pardo);

d) por intermédio de um juízo de ponderação e de adequação dos princípios/bens/valores constitucionais, conduzindo a uma concordância prática." 83

Todas estas teorias foram confrontadas e defendidas por vários ordenamentos jurídicos, tendo em vista suas incompletudes e verdades, sem contudo encontrar uma delas que pudessem, de forma plena, trazer as soluções aos problemas ou respostas unânimes.

A intimidade, em seu sentido amplo, ainda que o objeto aqui tratado seja da limitação da liberdade de expressão e informação, pode também sofrer restrições por atuação legislativa de forma direta ou indireta neste caso, a partir da conformação de outro direito, competência ou bem constitucional, desde que obedecendo às exigências já consagradas no Direito Comparado (lei em sentido estrito, clareza e certeza em suas disposições, adequação, necessidade e proporcionalidade da medida e garantia da preservação do núcleo essencial daquele direito) ${ }^{84}$.

\footnotetext{
${ }^{83}$ SAMPAIO, José Adércio Leite. Op. cit. p. 381. (nota)

${ }^{84}$ ALEXY.Teoría de los derechos fundamentales. Trad. Ernesto Garzón Valdés. Madri: Centro de Estudos Constitucionais, 1993. p. 87 et seq., CANOTILHO, J. J. Gomes. Direito Constitucional. $5^{\mathrm{a}}$ ed. Coimbra: Almedina, 1992. p. 622-633, 660-661. Apud: SAMPAIO, José Adércio Leite. Op. cit. p. 384 .
} 
No que respeita à sua violação, William Prosser dividiu em quatro categorias as formas de invasão a esse direito, comumente resolvidas pelos tribunais, quais sejam:

a) referente ao retiro, à solidão ou a assuntos privados, independente dos meios utilizados - físico, visual ou eletrônico;

b) divulgação pública de fatos privados, sobretudo aqueles aptos a causar constrangimento às pessoas;

c) divulgação pública de fatos falsos imputados a um indivíduo;

d) apropriação do nome, imagem ou de outros atributos da personalidade sem o conhecimento do interessado, visando à obtenção de lucro. ${ }^{85}$

Parece claro, por outro lado, que as pessoas públicas, conquanto possuam uma esfera da vida privada protegida de intervenções, gozam de diferente proteção à intimidade em relação às pessoas privadas ${ }^{86}$. “O momento em que alguém se coloca diante do público, ou aceitando cargo público, ou ao tornar-se candidato a cargo público, ou como artista ou homem de letras, ele rende-se ao seu direito à privacidade e obviamente não pode reclamar de nenhuma descrição justa ou de como o expõem". 87 Abdicam, pois, de parte de sua vida privada como suposto preço da fama conquistados.

Não se trata, entretanto, de supressão da privacidade, mas de restrição, haja vista que "sobre fatos íntimos, sobre a vida familiar, sobre a

85 CAVERO, José Martínez de Píson. El derecho a la intimidad en la jurisprudencia constitucional. Madri: Civitas, 1993. p. 32-33; DOTTI, René Ariel. Proteção da vida privada e liberdade de informação: possibilidade e limites. São Paulo: Revista dos Tribunais, 1980. p. 180. Apud: FARIAS, Edilsom Pereira de. Op. cit. p. 142.

${ }^{86}$ Tribunal de Justiça do Rio de Janeiro. Agravo de Instrumento n. ${ }^{\circ} 2003.002 .22453$ / $8^{\mathrm{a}}$ Câmara Cível. "As pessoas detentoras de cargos públicos, ou a que a eles aspiram, que tenham como função o gerenciamento das finanças públicas, têm, por razões óbvias, reduzida a proteção à esfera da intimidade."

Tribunal de Justiça do Rio de Janeiro. Apel. Cível n. ${ }^{\circ} 2004.001 .08520$ / 11 $1^{\text {a }}$ Câmara Cível. "Os esportistas que se tornaram figuras cercadas de notoriedade, perdem substância na sua intimidade. Notadamente no meio futebolístico, onde grassam a fama e o prestígio, mas também, forte desequilíbrio emocional conducente ao uso de expressões mais duras e vulgares. Não há ilícito civil se a verdade se encontra em parte da notícia e na outra a divulgação emprega expressão corrente no meio popular."

${ }^{87}$ HIXSON, Richard. Privacy in a public society. Nova Iorque: Oxford University Press, 1987. p. 38. Apud: FARIAS, Edilsom Pereira de. Op. cit. p. 143. 
reserva do domicílio e na correspondência não é lícita a comunicação sem consulta ao interessado. ${ }^{88}$

A notoriedade das pessoas célebres, assim como acontecimentos de interesse público ou realizados em público, ou ainda de interesse científico, didático ou cultural ou da ordem pública, e o comportamento da pessoa podem ser considerados, ainda, como limitações da privacidade em razão do interesse público.

Isso não autoriza, todavia, a livre utilização da imagem ou do nome de um indiciado, por exemplo. Assim como o réu e demais pessoas de qualquer modo "públicas", não ficam privados de seu direito à imagem: "fora das atuações imprescindíveis e diretamente relacionadas com o delito cometido, pode ele opor-se à divulgação de suas fotografias."

Até mesmo as pessoas de notoriedade podem vir a ter sua vida privada devassada em aspectos de sua personalidade em sua atividade profissional, mas não em temas de sua vida reservada. "Outras tantas pessoas envoltas em situações e eventos que despertaram o interesse público têm restringida a sua intimidade na exata medida dos acontecimentos, sem mais" 90 .

A pessoa pode ter dado consentimento para a divulgação dos fatos relativos à sua intimidade, sem representar uma ampla liberdade para que tais acontecimentos sejam difundidos. Tal autorização deve, entretanto, ter clareza quanto ao alcance e tempo determinado.

\footnotetext{
${ }^{88}$ BITTAR, Carlos Alberto. Op. cit. p. 104. Apud: FARIAS, Edilsom Pereira de. Op. cit. p.143. Neste sentido: CARVALHO, Luiz Gustavo Grandinetti Castanho de. Op. cit. p. 56. Acrescenta este autor que "o que pode ser divulgado é a parte de sua vida - personalidade - de domínio público, como as atividades políticas; não a esfera privada, desconhecida do grande público." Cf., no mesmo sentido, SIQUEIRA CASTRO, Carlos Roberto. Op. cit. p. 543: "a imagem das pessoas cercadas de notoriedade pertence de certa forma ao domínio público, não obstante as reservas de sua intimidade estarem constitucionalmente protegidas contra as investidas abusivas de repórteres e curiosos em geral".

${ }^{89}$ BERTI, Silma Mendes. Direito à própria imagem. Belo Horizonte: Del Rey, 1993. p. 64. Apud: FARIAS, Edilsom Pereira de. Op. cit. p. 155.

${ }^{90}$ SAMPAIO, José Adércio Leite. Op. cit. p.393.;
} 
No mundo contemporâneo, uma das mais encontradiças formas de invasão da intimidade é a divulgação da imagem. Com efeito, esse problema só surgiu a partir da invenção da câmera fotográfica. Levando-se em conta o interesse público, se a imagem for captada em contexto de ambiente aberto ao público, aderindo ao local ou ao acontecimento, não há que se falar em lesão à imagem. Contudo, se a fotografia demonstra o objetivo de explorar a imagem de alguém de forma não-autorizada, deverá prevalecer o direito à imagem, já que, neste caso, não se pode falar em liberdade de informação. ${ }^{91}$

Por seu turno, a proteção jurídica à honra, nomeadamente a penal, limitada como os demais direitos da personalidade, encontra como baliza a exceção concernente à verdade ou à notoriedade do direito atribuído àquela pessoa ofendida, cabível somente no Direito brasileiro em determinadas hipóteses, a saber: na calúnia (artigo 138 do Código Penal) é, em regra, permitida, salvo nos casos indicados no $\$ 3^{\circ}$ do aludido dispositivo; na difamação (artigo 139) a regra é a inadmissibilidade, aceitando-se apenas quando a ofensa imputada referir-se a funções públicas ou dirigida a funcionário público; por fim, na injúria (artigo 140), a exceção e vedada em qualquer hipótese.

Na contramão da doutrina afeita à ponderação de bens, há quem sustente uma relativa preferência do direito à intimidade quando em conflito com a liberdade de informação, como Aguilera Fernandéz.

Por exemplo, o suposto relacionamento amoroso fora do casamento de um político de destaque diz respeito à sua vida privada e à de sua família, representando-se irrelevante para o eleitor, já que esta informação nada afeta o exercício da função para qual foi eleito. Havia quem sustentasse que, por se tratar de crime, figuraria como uma licença ao direito à privacidade, já que "é entendimento corrente de que os crimes

\footnotetext{
${ }^{91}$ Nesse sentido: RE 95.872-0/RJ. Direito à imagem. Fotografia. Publicidade comercial. Indenização. "A divulgação da imagem da pessoa, sem o seu consentimento, para fins de
} 
podem e devem ser divulgados para o maior resguardo da sociedade" ${ }^{92}$. No Brasil, com a recente alteração do Código Penal para suprimir o crime de adultério de seu texto, isso importa menos ainda.

Em contrapartida a liberdade de expressão e informação, somada à perspectiva de instituição participante de forma decisiva na formação da opinião pública da sociedade democrática, é estimada como elemento condicionador da democracia pluralista e como pressuposto para o exercício de outros direitos fundamentais. Desta forma, na hipótese de confronto com outros direitos fundamentais ou bens constitucionalmente consagrados, os tribunais constitucionais têm decidido que, à primeira vista, a liberdade de expressão goza de posição, em tese, preferencial.

No dizer de Edilsom Pereira de Farias, os tribunais têm preferido o critério formulado pela Suprema Corte Norte-americana da preferred position em abstrato da liberdade de expressão. Isto se dá em razão da valoração dessa liberdade como condição indispensável para o ideal funcionamento de uma sociedade aberta, verificando se, precipuamente, o exercício da liberdade de expressão e informação está dentro do estabelecido como forma lícita de ação, a saber, respeitada a função social que esta liberdade desempenha no âmbito da sociedade democrática. Assim, se a informação diz respeito a assuntos ou sujeitos meramente privados, não há que se falar em valoração preferente da liberdade de expressão. Em um segundo momento, examina-se a "atitude diligente do comunicador no sentido de produzir uma notícia correta e honesta". 93

Com o advento da redemocratização do país, na qual a liberdade de imprensa desempenha função destacada no que se refere à formação da opinião pública, pela interpretação do artigo $220 \$ 1^{\circ}$ da Constituição de

publicidade comercial, implica em locupletamento ilícito à custa de outrem, que impõe a reparação do dano. (...)"

${ }_{92}$ FERNANDÉZ, Antonio Aguilera. La libertad de expresión del ciudadano y la libertad de prensa o información. Granada: Comares, 1990. Apud: CARVALHO, Luiz Gustavo Grandinetti Castanho de. Op. cit. p. 146.

${ }^{93}$ HERRERO-TEJEDOR, Fernando. Honor, intimidad y propia imgem. Madri: Colex, 1990. p. 108. Apud: FARIAS, Edilsom Pereira de. Op. cit. p. 154. 
1988, pode-se concluir que o confronto entre os direitos à intimidade, à vida privada, à honra, à imagem e a liberdade de expressão e informação, passa a ser resolvido na perspectiva de colisão entre direitos fundamentais, dentro do marco do direito constitucional, haja vista que anteriormente tal conflito era dirimido na esfera dos direitos contra a honra, nos termos da Lei de Imprensa.

Desta maneira, pode-se afirmar que, tal como a liberdade de expressão e informação possui na veracidade da informação veiculada um limite interno, a compatibilização com os sobreditos direitos da personalidade representaria um limite externo àquela liberdade. ${ }^{94}$

Conflito este que embora, prima facie, possa parecer de fácil solução, na verdade representa um desafio à dogmática dos direitos fundamentais, visto que não estão somente consagrados pela Constituição como limites àquela liberdade (artigo 220, $\$ 1^{\circ}$ ), mas também tutelados como direitos fundamentais em si mesmos $\left(\operatorname{artigo} 5^{\circ}, \mathrm{X}\right) .^{95}$

Fixados estes pontos, a limitação da liberdade de imprensa a partir da proteção ao direito à intimidade lato sensu será abordada tendo em vista as soluções já apresentadas até aqui, quais sejam a busca de uma regulamentação interna por parte dos órgãos de produção jornalística, as formas de reparação posteriores à consumação do dano e, por fim, os meios constitucionais e inconstitucionais de restrição àquela liberdade. A seguir, será proposto critério teórico privilegiado, que ofereça subsídios normativos, já no nível abstrato, para o aparente conflito de interesses.

\subsection{Auto-regulamentação}

A auto-regulamentação, também denominada auto-controle, seria exercida "pela própria classe jornalística, que, com o seu sentido de

\footnotetext{
${ }^{94}$ FARIAS, Edilsom Pereira de. Op. cit. p. 135.
} 
ética profissional e o sentido das responsabilidades, tem inequívoca vocação para ajuizar sobre os limites do exercício do direito à informação face aos restantes direitos do cidadão". 96

Como bem ressaltado por Eugênio Bucci, "a ética só existe porque a comunicação social é lugar de conflito". "A ética jornalística não se resume a uma normatização do comportamento de repórteres e editores: encarna valores que só fazem sentido se forem seguidos tanto por empregados da mídia como por empregadores - e se tiverem como seus vigilantes os cidadãos do público". 97

Nesta forma de controle, confere-se "à própria imprensa ou a órgãos integrados por jornalistas, donos e dirigentes de jornais, de periódicos e de agências de notícias, além de algumas pessoas sem vínculo com o setor, o controle da atividade jornalística, normalmente aplicando disposições constantes de um Código de Ética"98.

Em 1987, no Congresso Nacional dos Jornalistas, acontecido no Rio de Janeiro, foi votado e aprovado o Código de Ética dos Jornalistas Brasileiros, tendo como relator o jornalista Ronaldo Buarque de Holanda, segundo o qual "o exercício da atividade jornalística é de natureza social e de finalidade pública", desde que respeitados os seguintes deveres: “a) divulgar todos os fatos que sejam de interesse público; b) lutar pela liberdade de pensamento e expressão; c) defender o livre exercício da profissão; d) valorizar, honrar e dignificar a profissão (art. $9^{\circ}$ ); e) evitar divulgar fatos com interesse de favorecimento pessoal, para obter vantagens econômicas, de caráter mórbido ou contrário aos valores humanos (art. 13); f) ouvir sempre, antes de divulgar os fatos, todas as pessoas objeto de acusações não comprovadas, promovidas por terceiros e não

\footnotetext{
${ }^{95}$ Ibid. p. 170.

${ }^{96}$ FIGUEIREDO, Cristina. Comunicação social e direitos individuais. Seminário "Comunicação social e direitos individuais", realizado no Porto. Alta autoridade para a Comunicação Social, 1987, p. 84. Apud: FONTES JÚNIOR, João Bosco Araújo. Op. cit. p. 97.

${ }^{97}$ BUCCI, Eugênio. Sobre ética e imprensa. São Paulo: Companhia das Letras, 2000. p. 12.

${ }^{98}$ SAMPAIO, José Adércio Leite. Op. cit. p. 394.
} 
suficientemente demonstradas ou verificadas; e g) tratar com respeito todas as pessoas mencionadas nas informações a divulgar (art. 14)."99

Esta, no entanto, é mais uma tentativa de uma solução que desde o início se mostra insuficiente. Fontes Júnior defende que essa forma de controle das emissoras de televisão só seria possível com a existência de um órgão administrativo regulador da atividade, até porque alega que não há país algum que tenha deixado o controle absoluto da programação aos próprios concessionários. Sugere a adoção de sistema semelhante ao que ocorre nos Estados Unidos da América, qual seja, a criação de órgão regulador nos moldes da Federal Communications Commission (FCC), com amplos poderes diretivos, capaz de "gerar grande expectativa quanto à renovação das concessões, diante das sérias exigências da Comissão”. 100

Já existe, no Brasil, o Conselho de Comunicação Social (artigo 224, CF), como órgão auxiliar do Congresso Nacional, instituído pela Lei n. ${ }^{\circ} 8.389$, de 30 de dezembro de 1991, com competência para elaboração de estudos, pareceres, recomendações e outras solicitações encaminhadas pelo Congresso Nacional a respeito da Comunicação Social. Não se afigura, contudo, como meio eficaz para controle de tal atividade, em virtude da falta de pluralidade na escolha de seus componentes e do caráter político das suas decisões, como veremos adiante, dentre outras inaptidões.

Segundo a lei que instituiu o Conselho de Comunicação Social, a composição se daria da seguinte forma:

"Art. $4^{\circ}$ - O Conselho de Comunicação Social compõe-se de:

I - um representante das empresas de rádio;

II - um representante das empresas de televisão;

III - um representante de empresas da imprensa escrita;

\footnotetext{
${ }^{99}$ ROCHA, Eládio Torret. Ética, liberdade de informação, direito à privacidade e reparação civil pelos ilícitos de imprensa. Revista dos Tribunais. Vol. 793. novembro 2001. p. 83.

${ }^{100}$ FONTES JÚNIOR, João Bosco Araújo. Op. cit. p. 98.
} 
IV - um engenheiro com notórios conhecimentos na área de comunicação social;

V - um representante da categoria profissional dos jornalistas;

VI - um representante da categoria profissional dos radialistas;

VII - um representante da categoria profissional dos artistas;

VIII - um representante das categorias profissionais de cinema e vídeo;

IX - cinco membros representantes da sociedade civil."

A Federação Nacional dos Jornalistas alega que na última eleição para a composição deste órgão, em 22 de dezembro de 2004, houve suposta concentração das decisões pelas Casas Legislativas, levando a uma formação desequilibrada, verificada na "hipertrofia de representação de um único setor da comunicação social nas vagas destinadas a outras entidades da sociedade civil"101. Outro problema foi o "baixo grau de pluralidade" a que alude a Carta Aberta elaborada pela própria Federação Nacional de Jornalistas, bem como outras entidades, referindo-se tanto à representatividade da sociedade civil, como ao "predomínio de vagas para representantes do setor de televisão aberta" em relação a outros setores da comunicação social.

A Associação Brasileira das Emissoras de Rádio e Televisão ABERT - constituiu, em 1993, o Código de Ética da Radiodifusão Brasileira, comprometendo-se a "transmitir apenas o entretenimento sadio e informações corretas", rejeitando a promiscuidade sexual, a exploração da boa-fé do público e a violência. ${ }^{102}$

Recentemente, foi trazida à referência a criação do Conselho Federal de Jornalismo, através do Projeto de Lei n. $3985 / 2004$, com o objetivo de fiscalizar o exercício da profissão de jornalista. A proposta foi

\footnotetext{
${ }^{101}$ COORDENAÇÃo executiva Fórum Nacional pela Democratização da Comunicação. Faltou equilíbrio na nova composição do Conselho de Comunicação Social. Disponível em: <http://www.fenaj.org.br/materia.php?id=371> Acesso em: 16 mai. 2005.
} 
recebida com grande indignação tanto por parte dos oposicionistas, como dos governistas, além de repudiada pela própria classe, que via naquela uma forma mascarada de censura, haja vista o momento histórico em que se operou, permeado de escândalos políticos. O projeto de lei trouxe de volta o debate sobre a relação entre imprensa e o governo.

Sem falar sobre a criação do Conselho Federal de Jornalismo, mas aproveitando-se do contexto, o presidente do Supremo Tribunal Federal, em defesa da liberdade de imprensa, defendeu que a criação de um tribunal de ética por parte da própria categoria seria saudável. ${ }^{103}$

O grande problema neste caso é a inexistência de uma instância responsável por "apurar" os abusos do profissional, o que inviabiliza eventuais punições nos moldes do que ocorre com o Conselho Federal de Medicina e com a Ordem dos Advogados do Brasil, nos quais há um conselho de ética e disciplina.

Recentemente, os parlamentares da Comissão de Seguridade Social e Família estão analisando o Projeto de Lei 1600/03, que introduz o Código de Ética da programação televisiva, através do qual as emissoras de televisão responsabilizam-se pela idoneidade das informações, de forma a oferecer diferentes versões de um mesmo fato, e garantindo o direito ao contraditório na mesma matéria e com igual espaço ao oferecido à denúncia ou reclamação, sempre que versarem sobre conteúdo prejudicial à imagem de pessoas ou entidades. Esta forma de controle não é, contudo, autoregulamentação da atividade de imprensa, mas um controle externo por parte do poder público, mas que vem encontrando apoio em alguns segmentos da classe.

Sobre privacidade, o Código prevê que seja garantido o direito no tocante à gravação de imagens, salvo se obtidas em locais de circulação pública, não podendo, mesmo neste caso, “expor pessoas ao ridículo ou

\begin{tabular}{l}
\hline 102 CÓDIGO de ética da radiodifusão brasileira. \\
<http://www.abrajet.com.br/links/leis/coderb.htm> Acesso em 08 jun. 2005. \\
103 JOBIM defende 'tribunal de ética' para jornalistas. Jornal O Globo. O País, 17/08/04.
\end{tabular}


ocasionar algum tipo de constrangimento moral". ${ }^{104}$ As emissoras também deverão cuidar para que seus profissionais, em circunstâncias de tragédias ou de crimes violentos, não "contribuam para aumentar a angústia das pessoas que experimentam sofrimentos ou tragédias pessoais, com solicitações de entrevistas ou gravação de imagens", nem divulguem a identidade de pessoas mortas de forma a identificar os cadáveres.

Ademais, a composição do suposto "tribunal de ética" poderia trazer mais problemas, em razão da natureza peculiar da profissão de jornalista e da sua estrutura, caracterizada por fortes desigualdades de poder ideológico e financeiro.

Esta, sem embargo das críticas já apresentadas, seria a forma mais adequada para promover eventual condicionamento pontual à atuação profissional do jornalista, já que partiria da própria classe, sem intervenção estatal quanto à imposição de critérios e punições, o que poderia tender para a censura ou repressão, como o que ocorreu com o PL 3985/2004.

A sua insuficiência, contudo, não representa impossibilidade. A partir de razoáveis concessões recíprocas entre os próprios integrantes da classe, visando a melhoria do nome da profissão, estaria assegurada a viabilidade desta solução. Sempre guardando a liberdade de imprensa face ao Poder Público.

A esse respeito, ensina Eugênio Bucci que:

"Normas gerais e ética jornalística, porem, não se confundem. As primeiras têm sua validade e sua eficácia asseguradas pelo Estado. Quanto aos códigos de ética que existem na imprensa, surgem como a manifestação da consciência da profissão ou da empresa ou da organização. Expressam um comprometimento voluntário com um determinado padrão de conduta. (...) A validade dos códigos de estica está no compromisso prévio que eles contêm e no acúmulo de sabedoria ética que representam." 105

\footnotetext{
104 FELÍCIA, Ana. Privacidade. Agência Câmara. Disponível em <http://www3.camara.gov.br/internet/agencia/imprimir.asp?pk=48191>. Acesso em 30 abr 2005.

105 BUCCI. Eugênio. Op. cit. p. 206.
} 


\subsection{Censura}

A censura de natureza política, ideológica e artística, no âmbito da comunicação social, foi banida com o artigo $220, \S 2^{\circ}$ da Constituição Federal, bem como a censura, de qualquer natureza, no campo do direito individual, em função do artigo $5^{\circ}, \mathrm{X}$, relativas à liberdade de imprensa e à liberdade de expressão. Nesse sentido, haveria uma função social da imprensa e da sua liberdade de informação jornalística ${ }^{106}$.

Acrescenta o autor que a censura, como negação à liberdade de expressão, configura-se como "instrumento abominável porque, ainda quando prevista para a defesa de certos valores da sociedade, acaba por desnaturar-se e pôr-se a serviço da sustentação política dos governantes", o que faz com que sejam estabelecidos alguns limites ao gozo da liberdade de expressão e de imprensa, apenas através da previsão de outros direitos constitucionalmente assegurados, em razão do princípio da unidade da Constituição.

Informa, ainda, que a vedação à censura deve ser interpretada extensivamente, abarcando tanto a censura administrativa, "de caráter prévio à expressão ou informação originária”, como a posterior, "materializada em proibições de difusão ou divulgação (proibição de index)" 107 .

J. Cretella Jr. define censura como "o exame a que determinadas autoridades governamentais, moralistas ou eclesiásticas, submetem os meios de comunicação humana (livros, jornais, discursos, sermões, filmes, teatro, televisão, rádio), conforme padrões discricionários fixados pelo centro ou poder dominante dentro de determinados limites, estabelecidos em lei, podendo ser prévia ou a priori", impedindo a transmissão da

\footnotetext{
${ }^{106}$ BASTOS, Celso Ribeiro. Op. cit. p. 45.

${ }^{107}$ BASTOS, Celso Ribeiro e MARTINS, Ives Gandra. Op. cit. p. 59.
} 
mensagem "e posterior, depois de concretizada a comunicação", apreendendo-se as publicações já feitas ou aplicando-se sanções aos infratores. ${ }^{108}$

Não se confunde, contudo, com controle de legalidade, exercido pelo Poder Judiciário, que "tem o poder-dever, cautelar ou definitivo, de intervir na imprensa", como veremos adiante. ${ }^{109}$

A censura constitui mecanismo contrário ao regime constitucional das liberdades públicas ${ }^{110}$, visto que deseja impedir a circulação de opiniões, idéias. Para Manoel Gonçalves Ferreira Filho, “consiste na verificação, anterior à divulgação, da compatibilidade entre um pensamento que se quer exprimir e as normas legais vigentes", sendo-lhe inerente o caráter prévio. Destarte, em que pese as doutas opiniões divergentes, acima transcritas, a censura é sempre prévia; em momento posterior, não se trata mais de censura, mas de repressão ${ }^{111}$.

Não se confunde, ainda, com a informação produzida pelo Poder Público, acerca da natureza das diversões e espetáculos públicos, regulando faixas etárias, locais e horários em que suas apresentações manifestam-se inadequadas, por força do previsto no artigo $220, \S 3^{\circ}$ da Constituição. ${ }^{112}$

\footnotetext{
${ }^{108}$ CRETELLA Jr., José. Op. cit. p. 256.

${ }^{109}$ BULOS, Uadi Lammêgo. Op. cit. p. 1264.

${ }^{110}$ Ibid. p. 103.

${ }^{111}$ FERREIRA FILHO, Manoel Gonçalves. Comentários à constituição de 1988. $3^{\mathrm{a}}$ ed. São Paulo: Saraiva, 2000. p. 34.

112 Sobre a discussão relativa à censura, UTZERI, Fritz. Trash TV. Jornal do Brasil, Rio de Janeiro, 19 nov. 2000. p. 09.: "Qual a escolha que resta? A Banheira do Gugu? No limite? Linha direta? É esse o escopo educativo da TV brasileira? Caricaturar os índios, desrespeitá-los, até em sua religiosidade, como faz essa Uga uga? É em nome disso que se pretende defender a liberdade de expressão? Façam bom proveito dessa "liberdade". O que vejo é uma massificação da vulgaridade, do mau gosto, da sexualidade rastaqüera. Vejo uma proposta perniciosa que cultua "valores" e comportamentos inaceitáveis, como o estupro e até o incesto, que a moral comum sabe que estão errados."

"Não creio nem que tenha havido propósito de criar polêmica para elevar audiência de novela. Acho que é típica prepotência de um veículo que se arvora em todo-poderoso e acha que deve nortear o comportamento da sociedade, sob o pretexto de "realismo" e às vezes até de "denúncia". (E o pior é que, num país onde o nível de ignorância ainda é alto, esse padrão acaba por influir mesmo no comportamento geral).

Agora gritam contra a "censura". De fato, a dramaturgia global teve alguns embates com a censura, em novelas como Roque Santeiro, nos anos da ditadura. Mas foi só. No mais, a imagem que ficou foi a de aceitação (e até cumplicidade) do (com o) arbítrio e da privação de liberdades. Vi uma atriz, de talento incontestável, e de biografia impecável na luta pela liberdade, como Marieta
} 
Entende-se que a proibição da censura é genérica, haja vista ter sido prevista no que se refere à liberdade de expressão e não nos dispositivos relativos à liberdade de imprensa.

Não se pode negar que a experiência recente causou graves traumas à sociedade brasileira, mais especificamente com o regime militar, já que as produções intelectuais, artísticas e jornalísticas significavam um importante mecanismo de resistência.

Certamente o marco à restrição à liberdade de imprensa foi a edição do Ato Institucional n. ${ }^{\circ}$ 05, conferindo amplos poderes ao Presidente da República, Marechal Costa e Silva, "inaugurando os chamados 'Anos de Chumbo', uma longa e negra noite de terror" ${ }^{113}$. Dentre as suas prerrogativas estava a possibilidade da instituição da censura prévia dos meios de comunicação e das atividades artísticas, liberdades estas que só tiveram seu restabelecimento efetivo cerca de vinte anos após, com a promulgação da Constituição de 1988.

Tal circunstância, por mais que tenha servido de exemplo à atuação dos Poderes Públicos, não pode condicionar definitivamente a postura dos doutrinadores, legisladores e demais operadores do Direito. A Constituição de 1988 já estabeleceu a vedação a qualquer forma de censura à liberdade de expressão. Não se pode, entretanto, atribuir a qualquer intervenção do Poder Judiciário ou Legislativo, tendente a regular a liberdade de imprensa - sem restringir - visando tão somente a preservação de outros valores constitucionais, caráter de censura.

A censura ou qualquer outra medida tendente a restringir a liberdade de expressão e de imprensa é completamente contrária ao regime

Severo, indignada com a "censura". (Lembram-se do tempo em que Chico Buarque não aparecia nas telas da TV Globo?).

E, no episódio Riocentro, qual é mesmo o nome do general que deu sumiço nas fitas onde estava registrada a segunda bomba tirada do Puma e que a TV chegou a colocar no ar? Onde estava a Globo quando o povo brasileiro clamava por eleições diretas? Quem contribuiu ativamente para que Fernando Collor chegasse à Presidência, até editando ideologicamente e falseando um debate que Lula perdeu mas sem chegar a ser esmagado, como pareceu aos espectadores do Jornal Nacional? É essa gente que vem agora falar em censura? Ora...”. 
democrático, não podendo nunca representar uma solução aos abusos ao exercício daquela liberdade. Além de vedada por nosso ordenamento, a censura é completamente imprestável para o fim de tutelar a privacidade do indivíduo, já que configura, como vimos, ato do Poder Executivo no sentido de suprimir o pleno gozo da liberdade de expressão.

\subsection{Reparação civil e proibição de divulgar}

Como ressaltado por Barbosa Moreira, ao defender a constitucionalidade da intervenção do juiz nestas hipóteses, "inoperante a auto-regulamentação e limitada por dispositivos constitucionais a atuação do Poder Executivo, resta o controle judicial, que acha na Constituição inequívoco amparo"114.

O Poder Judiciário pode exercer o controle de legalidade da conduta exercida em razão da atividade de imprensa, com base no Código de Processo Civil (artigo 461), não configurando, no caso, censura, mas antes "o exercício da sua função constitucional de resolver e dizer o direito transformando o abstrato legal da norma na 'lei realidade' quando aplicada ao caso concreto, enquanto a censura", como já se falou no tópico anterior, “deve ser vista como ato, lei, regulamentos, enfim qualquer ato normativo do Poder Público que objetive, sob a visão política ou ideológica, limitar a atividade da imprensa livre" ${ }^{115}$, esta, sim, é indispensável ao Estado Democrático de Direito e não aquela que se baseia no "jornalismosensação-comercial".

\footnotetext{
${ }^{113}$ PILATTI, Adriano. Op. cit. p. 27.

${ }^{114}$ MOREIRA, José Carlos Barbosa. Temas de direito processual. oitava série. São Paulo: Saraiva, 2004. p. 273.

${ }^{115}$ CASTRO, Honildo Amaral de Mello. Op. cit. p. 215.
} 
É nesses casos que se pode falar em intervenção do Poder Judiciário como solução ao conflito entre o direito de informar do jornalista e o direito também individual à privacidade ${ }^{116}$.

A notícia que viola a esses direitos da personalidade pode na verdade estar escondendo desinformação, manipulação, interesses duvidosos, ideológicos, de forma a extrapolar a natureza informativa da matéria, dando margem ao controle de legalidade.

Importa definir a distinção entre notícia, opinião e propaganda. "A notícia é a difusão de um fato real e seu contexto", cabendo a ela, e somente a ela, dever da verdade. "Opinião é a aplicação de princípios a um fato real", apreciação subjetiva de um fato, não importando, quando desfavorável, abuso na liberdade de informação, na forma do artigo 27, I da Lei 5250/67. A propaganda, consistente nas mensagens e propagação de idéias, assim como a opinião, estão imunes da exigência da verdade. ${ }^{117} \mathrm{Na}$ hipótese da propaganda, há vedação expressa à publicidade enganosa, no artigo $37, \S 1^{\circ}$ da Lei 8.078/90, mas que não necessariamente importa em informação inverídica.

É por isso que "a honra, a dignidade e o bom nome de cada cidadão não pode, em nome do direito de informação, ser alvo de um juízo de valor tendencioso, mentiroso ou incorreto mais preocupado com o sensacionalismo que vende e que anuncia, do que com a veracidade dos fatos e com o compromisso da fidelidade com os seus eleitores." 118

\footnotetext{
${ }^{116}$ Como destacado por Honildo Amaral de Mello Castro acerca da relação Judiciário-imprensa: "Eu sei que a justiça se queixa muito dos jornais. Pode-se inaugurar um belo fórum. Se nesse momento isso não interessar ao meu público, não vou dar a notícia. Mas se o juiz fizer alguma coisa desagradável, escorregar na rua e se a história é boa, eu conto. O jornal é um negócio como outro qualquer." (Luiz Guttemberg, Editor-Chefe do Jornal de Brasília).

"E os justiceiros da TV, fazendo julgamento no lugar da Justiça. Estamos saindo disso agora. Nós fizemos o papel de investigadores, denunciadores, julgamos e executamos a sentença. Nós fizemos esse papel e cometemos vários erros de que devemos nos envergonhar, onde foram envolvidos a honra e o bom nome de pessoas que ficaram marcadas." (Alexandre Garcia, jornalista da Rede Globo).

${ }^{117}$ MALLEN, Ignácio Bel, ALFONSO, Loreto Corredoira y COUSIDO, Pilar. Derecho de la información. Madri: Colex, 1992. p. 116/117. Apud: CARVALHO, Luiz Gustavo Grandinetti Castanho de. Op. cit. p. 100.

${ }^{118}$ CASTRO, Honildo Amaral de Mello. Op. cit. p. 216.
} 
Não concordamos, todavia, com a assertiva radical de Honildo Amaral de Mello Castro, para quem "a notícia somente tem valor quando noticia escândalo ou traz sensacionalismo" ${ }^{119}$. Nem sempre isso ocorre. É evidente que a imprensa busca a todo o momento satisfazer o interesse da sua audiência e pode-se dizer que às vezes o faz trazendo notícias inverídicas ou parciais. Mas há notícias que têm capacidade de chamar atenção do público não somente em razão da manipulação do órgão de imprensa, mas em função de seus sujeitos e conteúdo. Um simples discurso infeliz do Presidente da República, por exemplo, por si só, mesmo sem qualquer comentário da empresa que divulga a matéria, despertam grande interesse do público. Esse público, a partir da notícia, faz seu próprio juízo de valor. Aqui releva, somente, o direito à verdade.

Como se sabe, "o noticiar falsamente tanto pode ser intencional, ou seja, doloso, como também culposo" ${ }^{120}$, isto é, mesmo o fato verdadeiro pode ser fortuitamente deturpado, o que surtiria os mesmos efeitos de um fato mentiroso, já que em ambos há a violação da verdade.

Tanto em um como noutro caso, não se pode alegar que a compensação ao lesado poderia advir do constitucionalmente previsto direito de resposta (art. $5^{\circ}, \mathrm{V}, \mathrm{CF}$ ), permitindo que seja explicado "o que foi noticiado com excesso, incorreto ou de maneira truncada, o que não é verdadeiro" 121 .

Por mais que o inciso IX do artigo $5^{\circ}$ da Constituição não preveja expressamente a possibilidade de responsabilização pelos abusos cometidos no exercício da liberdade de expressão, aplica-se-lhe o disposto à liberdade de manifestação do pensamento (art. $\left.5^{\circ}, \mathrm{V}, \mathrm{CF}\right){ }^{122}$

\footnotetext{
${ }^{119}$ CASTRO, Honildo Amaral de Mello. Op. cit. p. 221.

120 Ibid. p. 217.

121 Ibid. p. 221. Sobre o assunto, o mesmo autor traz interessante definição de como o direito de resposta, individualmente, não tem o condão de recompor o direito lesado: "Conta-se como caso demonstrador desta irrealidade do direito de resposta, que seria como se retirassem todas as penas de uma galinha, jogá-las para o alto para, depois, tentar recolocá-las nos seus verdadeiros lugares. Não h possibilidade de saber se quem ouviu a notícia também ouvirá o desmentido, ou para se fazer esse desmentido se renovará as agressões para novamente situar o fato".

${ }^{122}$ FERREIRA FILHO, Manoel Gonçalves. Op. cit. p. 36.
} 
Na mesma direção, Pontes de Miranda afirma que "a lei teria de proteger o ser humano, se o jornal mentiu, ou transmitiu mentira, às vezes mesmo calúnias. Tal tutela jurídica teria de consistir em medidas de direito material e de direito processual, que não sejam apenas o direito de resposta, e que afastem, com presteza e eficiência, os danos materiais e morais."

A reparação civil pelos ilícitos da imprensa, para alguns, representa a responsabilidade do Poder Judiciário, “a quem cabe fazer valer os parâmetros normativos constitucionais e infraconstitucionais, impondo, por isso mesmo, quando cabível, a reparação pecuniária pelo dano moral e/ou material caracterizados em face da não aplicação deontológica da liberdade de informação por aqueles que detêm o seu monopólio”, levandose em consideração a intensidade do dolo e o grau da culpa do ofensor, a intensidade do abalo sofrido pelo ofendido, a repercussão da notícia divulgada, as condições sociais, econômicas e financeiras do ofensor e do ofendido, apta à satisfação da dor deste e adequada a dissuadir aquele de igual conduta. ${ }^{124}$

De outra parte, com a criminalização dos atentados contra a honra, os tribunais, conforme ressaltado por Celso Ribeiro Bastos "125 " "têm prestigiado em muito o valor da verdade, tanto no que se refere à condenação criminal, quanto no que se refere à condenação cível (indenização). Isto é, em se provando que os fatos noticiados são verdadeiros, a jurisprudência é pacífica em não condenar os autores, valendo-se da exceção da verdade, no que se refere aos ataques a agentes públicos".

Entretanto, como já mencionado, mesmo os agentes públicos têm uma esfera de privacidade que não diz respeito ao público, pelo que discordamos com esta tendência. Não parece ser somente a veracidade que

\footnotetext{
123 PONTES DE MIRANDA, Francisco Cavalcanti. Liberdade de imprensa e censura. In: BONAVIDES, Paulo et. al. As tendências atuais do direito público. Rio de Janeiro: Forense, 1976. ${ }^{124}$ ROCHA, Eládio Torret. Ética, liberdade de informação, direito à privacidade e reparação civil pelos ilícitos de imprensa. Revista dos Tribunais. São Paulo, ano 90, v. 793, p. 88, nov. 2001.

${ }^{125}$ BASTOS, Celso Ribeiro. Op. cit. p. 48.
} 
condiciona o direito ou não à indenização. Assim é que entendemos ser cabível a indenização mesmo quando a notícia veiculada em atentado à honra (ou a qualquer outro direito da personalidade) for verdadeira, mas impertinente, isto é, não disser respeito ao interesse público, mas sim ao privado. Neste caso, a indenização só não será cabível quando verídica e pertinente a matéria jornalística, servindo esses critérios também, quando verificados, no cômputo da reparação dos danos morais e/ou materiais.

Segundo Gilmar Mendes, a redação protetiva do direito à privacidade, no artigo $5^{\circ}, \mathrm{X}$, não determinou que fosse possível apenas eventual reparação ao lesado, quando já se fosse verificado o dano. Esta redação, para o autor, só seria aplicada nos casos em que não se pode evitar a divulgação da matéria ofensiva ou lesiva. A proteção prévia estaria, conforme este entendimento, garantida no art. $5^{\circ}, \mathrm{XXXV}$, agindo o Poder Judiciário de forma acautelatória do direito ameaçado, evitando a configuração da lesão. ${ }^{126}$

Haveria, assim, uma tutela de urgência, preventiva ${ }^{127}$, acompanhada de outra, reparatória, consubstanciada na responsabilidade civil. As medidas principais dessa tutela preventiva poderiam constituir em “ordens de apreensão da publicação inteira sobre aspectos relevantes da intimidade de uma pessoa, desde que não se possam dissociar e, via de consequiência, ser retiradas do texto as expressões ou passagens que particularmente maltratem aquele direito."128

Esta forma de proteção à privacidade anterior à configuração da lesão, contudo, revela grandes e temerárias semelhanças com a proibição de

\footnotetext{
${ }^{126}$ MENDES, Gilmar Ferreira. Colisão de direitos fundamentais: liberdade de expressão e de comunicação e direito à honra e à imagem. Cadernos de Direito Tributário e Finanças. N. ${ }^{\circ} 05$, 1993. p. 16-20.

${ }^{127}$ Tribunal de Justiça do Rio de Janeiro. Apel. Cível. N. o 2003.001.26286 / 18ª Câmara Cível: "O controle judicial preventivo não se constitui em censura prévia, porquanto, proferido no exercício da prestação jurisdicional, atendeu ao princípio da proporcionalidade ante o caso de colisão complexa de direitos fundamentais, na prevalência do direito à intimidade ante à liberdade de imprensa, no caso, elevada a parâmetro indesejável, quando, em nome do interesse público, publica matéria declaradamente produto de violação por terceiro o sigilo das comunicações telegráficas. Desacato à delimitação ordenada pela norma do $\S 1^{\circ}$, do art. 220 da CF."

${ }^{128}$ SAMPAIO, José Adércio Leite. Op. cit. p. 421.
} 
divulgar própria da censura, já que torna difícil a apreciação do que deve ou não ser divulgado.

Já a responsabilidade civil é prevista no próprio texto constitucional, podendo ser o dano de ordem material ou moral e ainda à imagem, cuja reparação pode ser dar mediante retratação do ofensor, direito de resposta conferido ao ofendido, prestação de medidas destinadas a impedir ou fazer cessar os atentados à intimidade, ou, por fim, mediante a reparação pelo equivalente (dano patrimonial).

\subsection{Mídia e interesse público}

Apresentado o aparente conflito entre a liberdade de expressão, mais especificamente, a liberdade de imprensa e o direito à privacidade, e estabelecido que a função da mídia não é definir regras, mas difundir a verdade, "rapidamente, com exatidão e imparcialidade" ${ }^{129}$, pode-se chegar à nítida conclusão, como até já se esboçou neste trabalho, que só se pode falar em liberdade de imprensa sem restrições de qualquer natureza quando a informação trazida ao público estiver revestida de veracidade, imparcialidade e, mais que isso, de interesse público.

Como já se aventou, a liberdade de imprensa goza de posição preferencial, em tese, com relação aos demais direitos que eventualmente com ela se choquem. Esta presunção, entretanto, é elidida quando incorrer o órgão ou pessoa titular desse direito em abuso, violando de forma ilegal e inconstitucional direitos da personalidade, consoante estabelecido no artigo 220, $§ 1^{\circ}$ da Constituição de 1988. “A liberdade de imprensa é um princípio inegociável, ele existe para beneficiar a sociedade democrática em sua dimensão civil e pública" ${ }^{130}$, devendo, sem representar contradição, pelo

\footnotetext{
129 JOHNSON, Paul. Comunicação e ética. Rio de Janeiro: Série de Conferências do Instituto Liberal, 1994. p.1. Apud: ZIMMERMANN, Augusto. Op. cit. p. 698.

${ }^{130}$ BUCCI, Eugênio. Op. cit. p. 12.
} 
princípio da unidade da Constituição, observar os demais dispositivos daquela.

Não basta que a informação divulgada reflita a verdade dos fatos, veiculada de forma imparcial. É preciso que naquela informação haja o interesse da audiência. Isso se explica porque a esfera da intimidade relativa ao segredo e à vida familiar, mesmo em se tratando de pessoas dotadas de ampla notoriedade, devem ser mantidas protegidas de intervenções de terceiros não-autorizados.

Assim, quando a informação, exercida sob a guarida da liberdade de expressão, não estiver amparada pelo interesse público, configurará em abuso a este direito.

Não se quer aqui dar margem a supostos exageros de políticos, por exemplo, que, ao tratarem de assuntos que dizem respeito a seus eleitores, optem por manter aqueles fatos amparados por uma "pretensa" tutela à intimidade.

Privacidade não é somente o que se quer que não fique divulgado, sobretudo quando se trata de pessoas públicas. Há acontecimentos que não só têm autorização para ser divulgados, como em prol da sociedade democrática e aberta devem ter publicidade.

Exemplos recentes demonstram claramente esse conflito. A repercussão da reportagem publicada pelo New York Times, sobre o suposto hábito de beber do presidente Lula não parece dizer respeito a interesse público algum. A menos que tal hábito consista em um vício que o impossibilite de exercer as funções públicas para as quais foi eleito.

Por outro lado, o envolvimento do assessor da Casa Civil da Presidência Waldomiro Diniz com a corrupção nos jogos de loteria explorados oficialmente, junto com o bicheiro Carlinhos Cachoeira, não se pode dizer que se trata de assunto restrito à intimidade. 
Deste modo, sem adentrar no mérito de suas classificações, deve-se distinguir o interesse meramente privado do público. Este é o "conceito de bem geral, ou seja, o interesse geral da coletividade como um todo", não coincidindo "com o interesse do Estado enquanto pessoa jurídica", nele englobados, na sua noção ampla, os direitos difusos coletivos e individuais disponíveis ${ }^{131}$.

Já o interesse privado tem como titular a pessoa humana, e refere-se ao indivíduo isoladamente considerado, ao passo que o interesse público, de acordo com uma outra definição, sob uma acepção política, não se confunde com a soma dos interesses individuais ou dos grupos sociais, mas constitui uma "arbitragem" entre os interesses particulares. Na acepção jurídica, "tem por base a questão da competência para a arbitragem entre os interesses particulares", competência esta que pode decorrer da própria Constituição ${ }^{132}$.

Nesse sentido, importa definir que o interesse privado toma em linha de conta a concepção pessoal da vida digna e das suas necessidades, enquanto o interesse público, de titularidade do Estado, por se tratar de pessoa não humana, pessoa jurídica, não tem necessidade, mas finalidade.

E esse interesse (público) tem como característica ser o “interesse do todo, (...) 'função' qualificada dos interesses das partes, um aspecto, uma forma específica, de sua manifestação." 133

Assim como não se pode trazer fatos do público para o privado, não cabe ocultar fatos de índole pública, acobertando-as pela proteção constitucional da intimidade.

Desta forma, fica claro que, quando o assunto circunscreve-se ao plano privado e é indevidamente divulgado através dos meios de

\footnotetext{
${ }^{131}$ MAZZILLI, Hugo Nigro. A defesa dos interesses difusos em juízo. $8^{\mathrm{a}}$ ed. São Paulo: Saraiva, 1996. p. 03-04

${ }^{132}$ MANCUSO, Rodolfo de Camargo. Interesses difusos: conceito e legitimação para agir. $4^{\mathrm{a}}$ ed. São Paulo: Revista dos Tribunais, 1997. p. 29-32.

${ }^{133}$ BANDEIRA DE MELLO, Celso Antônio. Curso de Direito Administrativo. $15^{\text {a }}$ ed. São Paulo, Malheiros, 2003. p. 51. (grifo do autor)
} 
comunicação social, não há que se falar em restrição à liberdade de imprensa, mas em limite constitucionalmente previsto. Ou seja, não há liberdade de imprensa quando o assunto em questão estiver vinculado apenas ao íntimo das pessoas.

Assim entende Flávia Viveiros de Castro, ao afirmar que "a garantia da liberdade de expressão só pode existir em consonância com o texto constitucional. Só há, em consequiência, direito à liberdade de imprensa se este não ofenda valores constitucionalmente consagrados, como o são aqueles referentes à honra, imagem e intimidade. Qualquer matéria, notícia, programa, informação que ofender a imagem ou a reputação alheia não pode ser tolerada pela Lei Maior, uma vez que está fora dos limites protetivos da Carta Constitucional: é comportamento ilícito; não o exercício regular de um direito." 134

Por outro lado, se a matéria é de interesse público, não se pode invocar o direito à intimidade, pois este não é meio capaz de restringir a liberdade de imprensa quando interessar aos demais cidadãos.

Essa visão pode parecer hipótese de utilização do método da ponderação de interesses, mas não é. Não importa em sacrifício de um direito em razão de outro de mesma estatura constitucional, mas de total inexistência naquela situação - e não no caso concreto. Trata-se de limitação, no sentido conferido por Jorge Miranda. Não há possibilidade de situações semelhantes revelarem soluções diversas.

Entretanto, havendo o interesse público caracterizado nos moldes aos quais antes aludimos, não se pode falar em direito à intimidade. E a esfera da intimidade não pode comportar exercício da liberdade de expressão ou de informação. Caso contrário estaríamos tratando de hipótese de abuso ao exercício dessa liberdade, cabendo as conseqüências legais de que já tratamos.

\footnotetext{
${ }^{134}$ CASTRO, Flávia Viveiros de. Op. cit. p. 11.
} 
De acordo com o entendimento que leva em consideração a ponderação dos direitos fundamentais, nada mais é que "uma contraposição de conflitos de interesses, estando de um lado o cidadão e seus direitos civis, e do outro o órgão de imprensa com sua liberdade de informação jornalística", restando, "ao Poder Judiciário, cuja atribuição constitucional precípua é a composição de conflitos, solucionar tal caso e, com o fím de restabelecer a ordem legal atacada, impor os limites concretos à liberdade de informação jornalística." ${ }^{135}$ Na realidade, quem impõe esses limites é a própria Constituição; ao Poder Judiciário só cabe declarar, no caso concreto, a observância dos limites já estabelecidos em abstrato.

Segundo Celso Lafer, baseado nos ensinamentos de Hannah Arendt, "a discussão do íntimo, transposta para o domínio público, normalmente se transforma na trivialidade do mexerico, banalizando o público." ${ }^{136}$ E é por isso mesmo que, por mais que represente a tutela da intimidade um afastamento do conhecimento de todos, ela configura também uma proteção do interesse público, assim como a salvaguarda da livre expressão.

Assim, tomando-se por base a real distinção entre vida privada e intimidade, sendo aquela "a que se desenvolve fora das vistas da comunidade", conhecimentos que o seu titular não quer que se tornem públicos, tais como as relações na escola, no trabalho, e esta "a vida em ambiente de convívio, no interior de um grupo fechado e reduzido" ${ }^{137}$, abrangidos neste a relação inerente ao círculo familiar, de amizade , baseado em relações de confiança, constata-se que, em razão do interesse público, somente poderá haver conflito entre a liberdade de expressão ou de informação em relação à vida privada e nunca em relação à intimidade, haja vista que esta não tem nenhuma comunicabilidade com a esfera pública. Não se trata de restrição à liberdade de imprensa, mas de delimitação

\footnotetext{
${ }^{135}$ BASTOS. Celso Ribeiro. Op. cit. p. 46.

${ }^{136}$ LAFER, Celso. A reconstrução dos direitos humanos: um diálogo com o pensamento de Hannah Arendt. São Paulo: Companhia das Letras, 1988. p. 269.

${ }^{137}$ FERREIRA FILHO, Manoel Gonçalves. Op. cit. p. 35
} 
constitucional do seu exercício, em respeito aos demais direitos fundamentais.

Em relação aos direitos da personalidade consagrados no artigo $5^{\circ}$, inciso $\mathrm{X}$, da Constituição, referentes à intimidade em todos os seus aspectos, aos olhos da imprensa só interessam, quando muito, o que se passa na vida privada dos indivíduos, sobretudo daqueles que representam alguma função, geralmente política, já que, no dizer de Rui Barbosa:

"A imprensa é a vista da Nação. Por ela a Nação acompanha o que lhe passa ao perto e ao longe, enxerga o que lhe malfazem, devassa o que lhe ocultam e tramam, colhe o que lhe sonegam, ou roubam, percebe onde lhe alvejam, ou nodoam, mede o que lhe cerceiam ou destroem, vela pelo que lhe interessa, e se acautela do que a ameaça." 138

Contudo, não obstante a proteção de todos estes direitos, tanto a intimidade como a informação, enquanto fundamentais individuais, não fere a ordem constitucional vigente a limitação da liberdade de expressão através da imprensa face àquele mesmo interesse público, constituindo verdadeira função social da atividade jornalística.

${ }^{138}$ BARBOSA, Rui. A imprensa e o dever da verdade. São Paulo: Universidade de São Paulo, 1990. p. 37. 


\section{Conclusão}

Tencionou-se, assim, a partir de uma análise conceitual dos direitos em conflito, bem como observando, de maneira crítica, as formas já apresentadas de limitação da liberdade de expressão, em especial da liberdade de imprensa, verificar esta possibilidade face ao direito à intimidade.

Vimos que esta limitação só se manifesta viável em razão da liberdade de expressão não ser um direito absoluto, assim também não o é o direito à privacidade, "no sentido de que a tutela deles encontra, em certo ponto, um limite insuperável na tutela de um direito igualmente fundamental, mas concorrente" ${ }^{139}$. Haverá hipóteses de conflito em que se verificará a necessidade de relativizar algum - ou alguns - dos direitos elencados no artigo $5^{\circ}$, inciso X, da Constituição de 1988. Nesses casos, o próprio constituinte já estabeleceu que, havendo abuso, poderá o ofendido ou lesado buscar reparação junto ao Poder Judiciário, na forma do artigo $5^{\circ}$, incisos V, X e XXXV, por exemplo.

Destaca-se, apenas a título de crítica, sobre a limitação dos direitos fundamentais a teoria da ponderação de interesses, a qual, a nosso ver, não oferece base para resolver o problema em tese, posto que tenha ganhado muitos adeptos recentemente. Primeiramente porque não revela novidades, mas tão-somente adaptações de teorias já utilizadas, criticadas e aperfeiçoadas em outros países, como a Espanha e a Alemanha. Em segunda análise, não consegue fornecer uma solução ideal ao conflito, qual seja, partindo de critérios genéricos capazes de abarcar todas as hipóteses em questão. Por isso, não é uma teoria hábil a embasar sequer a utilização de exemplos práticos às bases teóricas que a sustenta, já que, como vimos,

\footnotetext{
${ }^{139}$ Para Norberto Bobbio só haveria dois direitos fundamentais absolutos, quais sejam o direito de não ser torturado e o direito de não ser escravizado. BOBBIO, Norberto. A era dos direitos. Rio de Janeiro: Campus, 1992. p. 42.
} 
pode suscitar soluções diversas para hipóteses concretamente semelhantes, e até hipoteticamente idênticas.

É evidente que com isso não se pretende buscar um "engessamento" da matéria, mas partir de uma premissa genérica, com base em critérios pré-fixados, evitando o total arbítrio do julgador, nos casos em que se vislumbra o abuso. Este é verificado de forma nítida quando a matéria veiculada não se circunscreve no âmbito do interesse público, mas traz em si, ainda que não deflagrado, interesse escuso ou meramente dúbio.

É possível que não se encontre solução à questão do conflito entre esses dois direitos fundamentais. Talvez, quando se amenizarem as marcas da repressão à liberdade de expressão deixadas pela ditadura militar, fiquemos menos refratários ao estabelecimento de alguma forma de regulamentação da profissão dos jornalistas realizada pelos próprios, com o apoio do poder público.

Não pode ser criado órgão com a atribuição de disciplinar a atuação do jornalista, nem utilizar medidas judiciais legalmente previstas em virtude de alguns fatos isolados e com a intenção de, na verdade, restringir a liberdade de imprensa, utilizando meios que apenas na aparência demonstram-se constitucionais ou legais, mas que na sua essência revelamse verdadeiras tentativas de reafirmar o poder político, ideológico ou social.

Importante é lembrar que distinção entre limitação e restrição de direitos. A restrição, por configurar a "amputação" parcial e permanente de faculdades contidas originalmente no direito, jamais pode ser aceita para a liberdade de imprensa, sob pena de descaracterizar tão relevante direito fundamental, o qual reflete outros direitos igualmente essenciais como a liberdade de expressão jornalística e o direito à informação. A limitação, por outro lado, conquanto constitucionalmente prevista, atingindo apenas o exercício do direito, deve ser expressamente regulada, de forma a evitar que sua aplicação surta os mesmos efeitos de uma verdadeira restrição. 
Com efeito, a falibilidade dos tantos projetos de lei apresentados até hoje decorre, entre outros motivos, do fato de serem de iniciativa do governo ou de representantes do Poder Legislativo, tentando regular, e por vezes restringir ou limitar de maneira equivocada, um direito que só veio a atingir a sua plenitude com a Constituição de 1988. Somente quando, por razões de pressão popular ou conscientização dos próprios jornalistas, efetivamente se buscar a elaboração de um código de ética, sem perder de vista as experiências pretéritas e os avanços tecnológicos da mídia, poderemos contar com outra solução, ainda que tardia, aos abusos cometidos sob a guarida da liberdade de imprensa.

Por ora, em razão do período de consolidação democrática por que passamos - afinal a Constituição tem pouco mais de quinze anos -, a única possível resposta ao problema seja aquela exercida a posteriori pelo Poder Judiciário, objetivando a reparação do dano. Se defendêssemos a viabilidade da proibição de divulgar, sobretudo de forma cautelar, sem a observância do contraditório, estaremos permitindo a prática de atos como o que ocorreu com o jornalista Fernando Moraes, que teve determinada a retirada de circulação de todos os exemplares de seu livro "Na toca dos Leões", pelo juízo da $7^{\text {a }}$ Vara Cível de Goiânia, tendo ainda sido proibido de comentar o caso, sob pena de multa. ${ }^{140}$

Por fim, urge trazer novamente a distinção entre o direito à vida privada e o direito à intimidade quando em conflito - ou suposto conflito com a liberdade de imprensa.

Conforme tratamos anteriormente, a inviolabilidade da vida privada pode ensejar em alguns casos, em função do âmbito de proteção que a caracteriza, a sua limitação, sempre respeitado o interesse público.

\footnotetext{
${ }^{140} \mathrm{O}$ livro Na toca dos leões conta a historia da agência de propaganda W/Brasil. "No livro, Fernando Moraes reproduz uma conversa que teria acontecido entre o então candidato Caiado e o publicitário Gabriel Zellmeister, durante a campanha presidencial de 1989. No encontro, Caiado teria se referido aos nordestinos como estratos sociais inferiores. Teria dito ainda que um remédio adicionado à água poderia esterilizar as nordestinas." LIVRO censurado. Jornal nacional, Rio de $\begin{array}{lllll}\text { Janeiro, } & 07 & \text { mai. } & 2005 . & \text { Disponível }\end{array}$
} 
Entretanto, entendemos que o direito à intimidade não observa a mesma regra, pelo mesmo fundamento: o objeto tutelado. Na primeira hipótese, por tratar de assuntos e conhecimentos que o seu titular não quer que se tornem públicos, por concernir à vida que o indivíduo desenvolve alheia à coletividade, mas que perfeitamente poderiam ser transpostos ao domínio público, eventualmente seria gerado algum conflito. Contudo, o direito à intimidade, por representar a salvaguarda de relações de caráter íntimo, mais do que simplesmente não se comunicarem com o público, ao público nunca interessam.

"É inadmissível, por não ser notícia legítima o uso de qualquer denúncia sobre hábitos e convicções íntimas de alguém - quanto a religião, sexo etc. - a não ser quando esse alguém buscar prestígio ou lucro na vida pública mentindo a respeito." ${ }^{141}$

Assim, poder-se-ia afirmar que a função social da atividade jornalística estaria plenamente constatada quando fosse percebida a máxima observância dos direitos constitucionais fundamentais, inclusive a liberdade de expressão, mesmo limitada, desde que acrescido dos seus elementos "recomendáveis", tais como a imparcialidade na divulgação da notícia, a sua pertinência, a veracidade e a segurança da fonte, o interesse público. Ou dito de outra maneira:

"Em circunstancias ideais, os profissionais serão curiosos, sempre; preocupados com o interesse público, o tempo todo. Dedicados a tornar melhor - e também mais divertida - a vida do leitor, idem." ${ }^{142}$

<http://jornalnacional.globo.com/Jornalismo/JN/0,,AA958685-3586-299340,00.html>. Acesso em: 18 mai. 2005.

${ }^{141}$ GARCIA, Luiz. Investigativos e investigadores. $O$ Globo, Rio de Janeiro, Opinião, Edição de 06 mai. 2005, p. 07.

${ }^{142}$ Ibid., loc. cit. 


\section{Bibliografia}

AIETA, Vânia Siciliano. A garantia da intimidade como direito fundamental. Rio de Janeiro: Lumen Juris, 1999.

BANDEIRA DE MELLO, Celso Antônio. Curso de Direito Administrativo. $15^{\mathrm{a}}$ ed. São Paulo, Malheiros, 2003.

BARBOSA MOREIRA, José Carlos. Temas de direito processual: oitava série. São Paulo: Saraiva, 2004.

BARBOSA, Rui. A imprensa e o dever da verdade. São Paulo: Universidade de São Paulo, 1990.

BARROSO, Luís Roberto. Liberdade de expressão, censura e controle da programação de televisão na Constituição de 1988 (parecer). In

Temas de direito constitucional. Rio de Janeiro: Renovar, 2002. 2a ed. p. 341-387.

- Colisão entre liberdade de expressão e direitos da personalidade. Critérios de ponderação. Interpretação constitucionalmente adequada do Código Civil e da Lei de Imprensa. Revista Trimestral de Direito Civil. Rio de Janeiro, ano 4, v.16, p.59-102, out.- dez. 2003

BASTOS, Celso Ribeiro e MARTINS, Ives Gandra. Comentários à Constituição do Brasil. São Paulo: Saraiva, 1989.

BASTOS, Celso Ribeiro. Os limites à liberdade de expressão na Constituição da República. Revista Forense. Rio de Janeiro, ano 96, v. 349, p. 43-51, jan.- fev.- mar. 2000.

BOBBIO, Norberto. A era dos direitos. Rio de Janeiro: Campus, 1992.

BUCCI, Eugênio. Sobre ética e imprensa. São Paulo: Companhia das Letras, 2000. 
BULOS, Uadi Lammêgo. Constituição federal anotada. $4^{\mathrm{a}}$ ed. São Paulo: Saraiva, 2002.

CANOTILHO, J. J. Gomes. Direito Constitucional e teoria da constituição. $2^{\text {a }}$ ed. Coimbra: Almedina, 1998.

CARVALHO, Luiz Gustavo Grandinetti Castanho de. Liberdade de informação e o direito difuso à informação verdadeira. $2^{\mathrm{a}}$ ed. Rio de Janeiro: Renovar, 2003.

CASTRO, Flávia Viveiros de. A liberdade de expressão no contexto dos direitos fundamentais, a responsabilidade da imprensa e os tribunais. Disponível em <http://www.mundojuridico.adv.br>. Acesso em 09 dez 2004.

CASTRO, Honildo Amaral de Mello. Poder judiciário e imprensa: visão, realidade e prospectiva. Revista Brasileira de Direito Constitucional e Internacional. São Paulo, ano 10, n. ํ 40, p. 205-226, jul.- set. 2002.

CHAUI, Marilena de Souza. Espinosa: uma filosofia da liberdade. São Paulo: Moderna, 1995.

COORDENAÇÃO executiva Fórum Nacional pela Democratização da Comunicação. Faltou equilíbrio na nova composição do Conselho de $\begin{array}{llll}\text { Comunicação } & \text { Social. } & \text { Disponível }\end{array}$ $<$ http://www.fenaj.org.br/materia.php?id=371>. Acesso em 16 mai. 2005.

CRETELLA Jr., José. Comentários à Constituição de 1988. $3^{\text {a }}$ ed. Rio de Janeiro: Forense Universitária, 1994.

FARIAS, Edilsom Pereira de. Colisão de direitos: a honra, a intimidade, a vida privada e a imagem versus a liberdade de expressão e informação. $2^{\mathrm{a}}$ ed. Porto Alegre: Sergio Antonio Fabris Editor, 2000. 
FELÍCIA, Ana. Privacidade. Agência Câmara. Disponível em <http://www3.camara.gov.br/internet/agencia/imprimir.asp?pk=48191>. Acesso em 30 abr 2005.

FERREIRA FILHO, Manoel Gonçalves. Comentários à constituição de 1988. $3^{\text {a }}$ ed. São Paulo: Saraiva, 2000.

FONTES JÚNIOR, João Bosco Araújo. Liberdades e limites na atividade de rádio e televisão: teoria geral da comunicação social na ordem jurídica brasileira e no direito comparado. Belo Horizonte: Del Rey, 2001.

JABUR, Gilberto Haddad. Liberdade de pensamento e direito à vida privada. São Paulo: Revista dos Tribunais, 2000.

JOBIM defende 'tribunal de ética' para jornalistas. Jornal O Globo. O País, $17 / 08 / 04$

LAFER, Celso. A reconstrução dos direitos humanos: um diálogo com o pensamento de Hannah Arendt. São Paulo: Companhia das Letras, 1988.

LEONCY, Léo Ferreira. Colisão de direitos fundamentais a partir da Lei 6.015/97: o direito à imagem de presos, vítimas e testemunhas e à liberdade de expressão e de informação. Revista de Direito Constitucional e

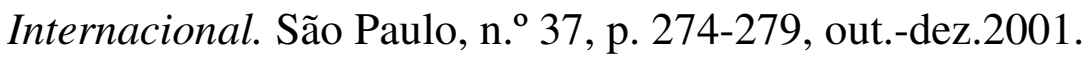

LEYSER, Maria de Fátima Vaquero Ramalho. Direito à liberdade de imprensa. Justitia. São Paulo, v. 63 (194), p. 87, abr.- jun. 2001.

LIVRO censurado. Jornal nacional, Rio de Janeiro, 07 mai. 2005. Disponível em: <http://jornalnacional.globo.com/Jornalismo/JN/0,,AA958685-3586299340,00.html>. Acesso em: 18 mai. 2005.

MANCUSO, Rodolfo de Camargo. Interesses difusos: conceito e legitimação para agir. $4^{\mathrm{a}}$ ed. São Paulo: Revista dos Tribunais, 1997. 
MATOS, Olgária Chain Féres. República, cultura e democracia midiática. In Retorno ao republicanismo. CARDOSO, Sérgio (org.). Belo Horizonte: Ed. UFMG, 2004. pp. 135-164.

MAZZILLI, Hugo Nigro. A defesa dos interesses difusos em juízo. $8^{\mathrm{a}}$ ed. São Paulo: Saraiva, 1996.

MENDES, Gilmar Ferreira. Colisão de direitos fundamentais: liberdade de expressão e de comunicação e direito à honra e à imagem. Cadernos de Direito Tributário e Finanças. n. ${ }^{\circ}$ 05, p. 16-20, out.- dez.1993.

MIRANDA, Darcy de Arruda. Comentários à lei de imprensa. $3^{a}$ ed. São Paulo: Revista dos Tribunais, 1995.

MORAES, Alexandre de. Direito constitucional. $8^{\text {a }}$ ed. São Paulo: Atlas, 2000. p. 60.

PILATTI, Adriano. Formação Constitucional do Brasil. Mimeo.

PONTES DE MIRANDA, Francisco Cavalcanti. Liberdade de imprensa e censura. In: BONAVIDES, Paulo et. al. As tendências atuais do direito público. Rio de Janeiro: Forense, 1976. p. 185-187.

ROCHA, Eládio Torret. Ética, liberdade de informação, direito à privacidade e reparação civil pelos ilícitos de imprensa. Revista dos Tribunais. São Paulo, ano 90, v. 793, p. 89-102, nov. 2001.

SAMPAIO, José Adércio Leite. Direito à intimidade e à vida privada: uma visão jurídica da sexualidade, da família, da comunicação e informações pessoais, da vida e da morte. Belo Horizonte: Del Rey, 1998.

SARMENTO, Daniel. A ponderação de interesses na Constituição Federal. Rio de Janeiro: Lumen Juris, 2000.

SILVA, José Afonso da. Curso de direito constitucional positivo. $19^{\mathrm{a}}$ ed. São Paulo: Malheiros, 2001. 
SIQUEIRA CASTRO, Carlos Roberto de. A constituição aberta e os direitos fundamentais. Rio de Janeiro: Forense, 2003.

UTZERI, Fritz. Trash TV. Jornal do Brasil, Rio de Janeiro, p. 09,19 nov. 2000 .

ZIMMERMANN, Augusto. Curso de direito constitucional. $2^{\mathrm{a}}$ ed. ampliada. Rio de Janeiro: Lumen Juris, 2002. 